\title{
A Persistent Force: \\ Violence in Maurice Gee's Historical \\ Novels for Children
}

By

Susan Armour

A thesis submitted to the Victoria University of Wellington in fulfilment of the requirements for the degree of

Master of Arts in New Zealand Literature

Victoria University of Wellington

2012 


\section{Contents}

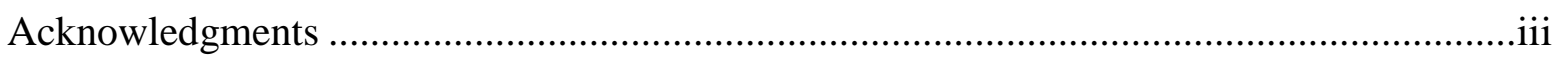

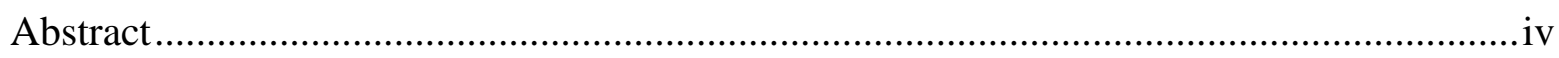

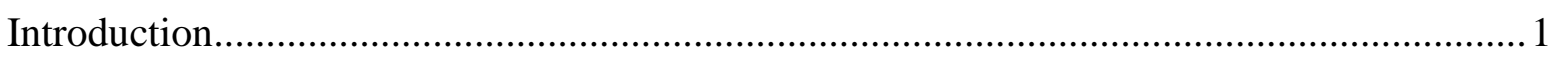

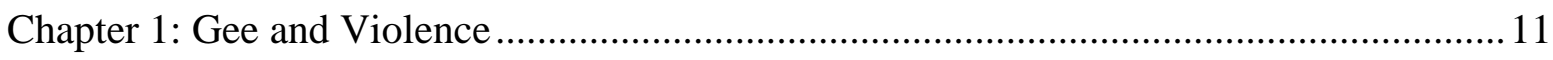

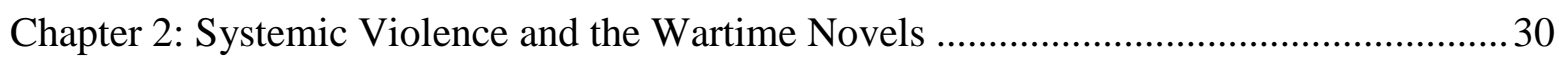

The Fire-Raiser ............................................................................................. 32

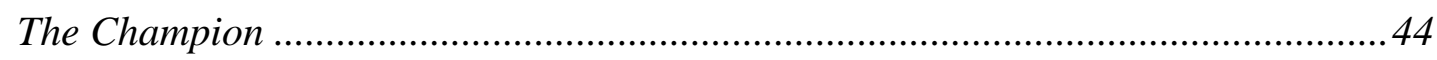

Chapter 3: "Expanding Scenes of Violence" in The Fat Man ...............................................55

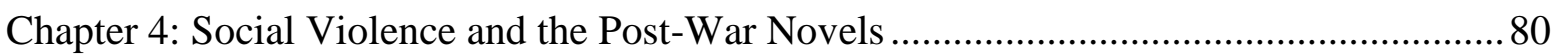

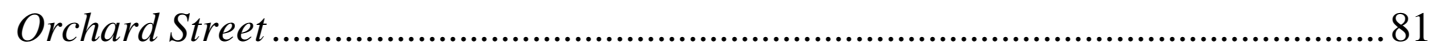

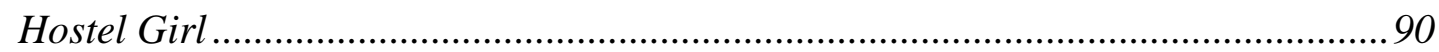

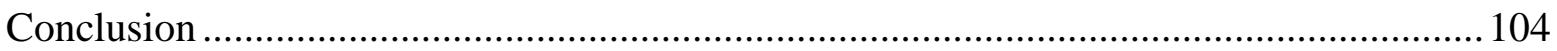

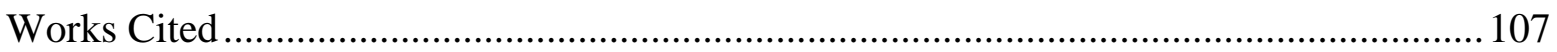




\section{Acknowledgments}

This thesis has taken a long time to write. It owes its survival to many people who have encouraged me to finish, even when that seemed impossible. My first thanks must go to my supervisor, Jane Stafford, for her helpful feedback on my drafts and leads to useful sources. Thank you to my family, friends and colleagues for their support, especially Jenny for filling in while I took study leave from work. Thanks also to the Open Polytechnic for generous research and development time and to Kayla Wyatt in the FHSS Office. Heartfelt thanks to my sister, Barb, who provided formatting help from Sydney.

To Bob, Andrew and Chris, special thanks for shouldering more of the load at home, picking up resources from libraries, helping with IT issues and supplying me with endless cups of tea. You now know more about Maurice Gee than you ever wanted to.

I dedicate this thesis to Betty and John, with love.

Susan Armour

April 2012 


\begin{abstract}
Since the publication of his first novel, The Big Season, in 1962, Maurice Gee's fiction for adults has been noted for its preoccupation with violence. But can we say the same of his fiction for children? And if so, how might that predisposition be reconciled for young readers? Using a predominantly literary-historical reading of Gee's fiction for children published between 1986 and 1999, this thesis attempts to answer these questions. Chapter 1 establishes the impact of violence on Gee's early years and its likely influence on his writing. Chapters 2-4 then consider the presence of violence in Gee's five historical novels for children. Chapter 2 focuses on the wartime novels, The Fire-Raiser and The Champion, and their respective depictions of war and racism, while chapter 3 explores individual, family and social violence as "expanding scenes of violence" (Heim 25) in The Fat Man. The fourth and final chapter discusses the two post-war novels, Orchard Street and Hostel Girl, where social violence runs as an undercurrent of everyday life. The thesis finds that violence - in different forms and at different intensities - persists across the novels and that Gee tempers its presence appropriately for his young readers. Violence, Gee seems to be saying, is part of the mixed nature of the human condition and this knowledge should not be denied children.
\end{abstract}




\section{Introduction}

In The Oxford Companion to New Zealand Literature in English, Nelson Wattie observes that Maurice Gee's fiction for adults has been criticised for its preoccupation with violence since the publication of his first novel, The Big Season, in 1962 (198). Examples that stay in the mind from Gee's early work are Celia Inverarity's brutal murder (In My Father's Den 1972), the skewering of the Kingsley family cat with a garden fork (Games of Choice 1976) and the beating and defilement of homosexual Alfred Plumb (Meg 1981). Those in the later work are equally disturbing. Tom Round sexually abuses his daughters (The Burning Boy 1990), Tod Scahill/Ralph Murdoch drowns his pregnant wife and daughters (Going West 1992) and Mrs Ponder is viciously murdered by Brent Rosser (Crime Story 1994).

Are Gee's historical novels for children similarly preoccupied with violence? And if so, how might that predisposition be reconciled for young readers?

\section{The Fat Man}

When Gee's The Fat Man won the AIM Junior Fiction Award and the AIM Children's Book of the Year Award in 1995, ${ }^{1}$ it sparked controversy, not over the novel's literary merit - everyone agreed it was well written - but whether its disturbing content was suitable for readers around eight to 13 years old (the age range of the AIM junior fiction category in which the novel was entered). ${ }^{2}$ According to Tessa Duder, writer of children's fiction and convenor of the 1995 AIM judging panel, the debate around The Fat Man focused on

\footnotetext{
${ }^{1}$ In the same year, it also won the Esther Glen Award (which is awarded annually to a distinguished work of New Zealand fiction for children).

${ }^{2}$ It must be noted that The Fat Man was placed in the junior fiction category of the AIM Awards for the purposes of the awards only, and on the condition that it came with a warning for parents, teachers and librarians that it may not be suitable for younger readers (Duder, Mills and Elder, June 14).
} 
whether junior readers "should be starting to read about vicious bullying, murder, revenge and finally complicity in an inevitable though just death" (Duder "Much Ado").

That debate played out mainly in the letters section of the New Zealand Listener between May and July that year, beginning with what was called a "forceful attack" (Duder, Mills and Elder, June 14) on the novel and the judging panel by Dorothy Butler, a New Zealand expert on children's reading. Others in the Butler camp included authors of children's fiction, Agnes-Mary Brooke (now Amy Brooke) and, later, Margaret Mahy. Butler accused the novel of "depriving children of their childhood" and suggested that it was "more likely to disturb or even damage the 9-12 year olds for whom it has been, astonishingly, written" (May 13, 12). She put forward other books that she considered more suitable for junior readers, including Margaret Mahy’s 1992 award-winning Underrunners (July 22, 13). Continuing the debate the next year, but in a more scholarly way, Uta Purcell's small-scale research on the implied reader of The Fat Man concluded that it was not a junior reader but "a more mature child who is worldly-wise and who has good reading skills" (50).

Supporters of The Fat Man claimed that those in the Butler camp were advocating the homogenising and censorship of children's literature, and suggested they were out of touch with the real world. Paula Boock (whose novel for young adults Dare Truth or Promise would be an even more contentious winner of the 1998 New Zealand Post Book of the Year) said: "Dark tales cannot be equated with depriving children of their childhood. Children have a natural awareness of cruelty and evil in the world" (July 1, 13). In the same issue of "Letters", Jack Lasenby, author of The Mangrove Summer (1988) and other children's books, argued for children's freedom to choose what they read, and asked, "Why should one child's reading be limited because of another's abilities or lack of them?" (July 
1, 13). Capping off the correspondence, three children gave their uncritical support to the novel (Johnson, Militch and Cresswell, July 22, 13).

The critical reaction to The Fat Man was unprecedented. Gee was forced to defend his novel: "I think it's a tough story. I don't quarrel with the people who say it's a tough and violent story. I meant to use pity and terror - which are a large part of fiction. But the story moves on through those things to some sort of satisfying resolution" (Gee, qtd. in Holloway 23). Gee also stressed the importance of judging the book as a whole and suggested that it was suitable for junior readers:

I knew that it might be judged as unpleasant and disturbing, but believed that this would be a misjudgement if the book was seen as a whole. I thought of it as being for older children, even a young adult book, and was surprised to find it entered in the junior section in the book awards. But even for the younger reader, and there have been many, it seems to provide a positive reading experience, and to find them not unready. ${ }^{3}$ ("Creeks and Kitchens" 25)

\section{The thesis}

In this thesis I investigate the presence of violence in Gee's five historical novels for children: The Fire-Raiser (1986), The Champion (1989), The Fat Man (1994), Orchard Street (1998) and Hostel Girl (1999). My study is, I believe, the first systematic response to an under-appreciated influence on these novels. As I will argue, violence - in different forms and at different intensities - persists across these novels for children and Gee treats its presence appropriately for his young readers. $^{4}$

\footnotetext{
${ }^{3}$ Young readers like his two grandsons, presumably, to whom he dedicated the novel.

${ }^{4}$ I have preferred the general description of the novels' audience as 'children' in the title of this thesis rather than as 'older children' or 'young adult', although I do make a case in chapter 4 for Orchard Street and Hostel Girl as YA novels.
} 


\section{What is violence?}

Jane and James Ritchie offer two definitions of violence that go well beyond the usual dictionary definitions focusing on physical violence. Although these definitions apply to violence in New Zealand society, they also seem appropriate to violence in literature. The first definition allows for harm as that inflicted by individuals and social rules and practices:

Violence is any action which harms another whether it is inflicted by a person or by social rules or practices which harm people. It is often physical, sometimes not, sometimes horrific, dramatic and attention grabbing but more often slow, insidious, constant and hidden. (Ritchie \& Ritchie, "The Rainbow Path" 8)

The second definition emphasises the inequality of violence with words we would associate with the perpetrator(s) - 'power' and 'force' - and words that we would associate with the victim(s) - 'induce' and 'submit'. This definition also introduces the idea of someone being 'violated' if they are forced to do something they do not want to do:

Individuals are violated when another person takes action against them which has the quality of power or force to induce them to, or to submit to, something they would rather not. (Ritchie \& Ritchie, Violence in New Zealand 7)

Violence takes many forms. As Christina Jarvis tells us, it can be physical, verbal, sexual or psychological. It can be inflicted by individuals, groups, institutions and nations. It can endanger people's lives and affect their wellbeing. It can range from personal violence to interpersonal violence and family violence to institutional violence (Jarvis "Violence"). We will see some of these representations of violence in the novels being studied in this thesis. 


\section{The historical novel}

The five novels in my study fit within the genre of the historical novel and follow many of its conventions. The historical novel dates back to the nineteenth century and Sir Walter Scott's Waverley novels. According to M.H. Abrams: "The historical novel not only takes its setting and some characters and events from history, but makes the historical events and issues crucial for the central characters and the course of the narrative" (230). Other critics note the genre's potential for "constant reinterpretation of historical events" (Czennia 71) and to "illuminate the present through the past" (Hourigan 171). One key to the appeal of the historical novel is its temporal and spatial distance from the concerns of everyday life. This distancing effect provides a buffer to challenging themes such as violence.

Significantly, writers of historical fiction are not bound by facts or historical accuracy in the same way that historians are. As Louise Clark states: "The need to provide narrative shape and interesting characters may lead writers to change facts to suit the exigencies of the story, or to combine real and fictional elements, such as placing invented characters in an historically authentic setting" ("Making Its Own History" 4). Gee, for instance, populates Orchard Street with some of the key players from the 1951 Waterfront Dispute (such as Prime Minister Holland and union leaders Barnes and Hill), which adds to the novel's verisimilitude.

The historical novel also offers what Harry Ricketts calls "identity-forming moments" (80) for its perceptive readers. In Gee's case, these moments revolve around the critical periods in New Zealand history which frame his stories. Thus, over the forty years the novels collectively cover, young readers get a sense of their national history and also of the developing New Zealand character. In The Fire-Raiser, for example, they may see the 
former in the emerging nationalism of the time and the latter in practical Hedges and Wix as well as the enterprising Phil with his flat vowels.

\section{Violence in children's literature}

Many people are concerned about the presence of violence in children's literature. Maureen Nimon asks, "Does violence have any place in children's literature?” (29), Carl Tomlinson claims that "[v]iolence cannot be avoided in literature, even literature for children, for literature serves to explain the human condition" (40) and Nicola Bartola argues that “[c]hildren's books can and must be a powerful medium in which the complex social and political sources of violence are illuminated and understood" (7).

Nimon points out that violence in children's literature is not a new phenomenon. In the past, she says, didactic stories for children commonly rewarded the exemplary child and, often, physically punished the recalcitrant one. Violence in these stories was used to admonish, instruct and punish. In another sense, violence in children's literature was seen as admirable. During the days of the British Empire, boys' magazines such as Chums extolled "the literature of imperialism" (Nimon 29) and encouraged boys to 'do their duty' in wartime. Other stories demanded that children show physical courage and be prepared to face danger or make the ultimate sacrifice. It is only quite recently that violence in children's literature has become so vigorously contested (Nimon 29-32).

Roald Dahl is one author whose use of violence in his junior fiction has been contested. His stories are loved by children but have often offended adults with their violence, along with their vulgarity and disrespect for authority (West, "Regression" 219). Consequently, Dahl's James and the Giant Peach (1961), Charlie and the Chocolate 
Factory (1964) and The Witches (1983) have all been banned at some time in school and public libraries overseas. Dahl, however, did not believe the violence in his books was gratuitous or age-inappropriate:

I do include some violence in my books, but I always undercut it with humour. It's never straight violence and it's never meant to horrify. I include it because it makes children laugh. Children know that the violence in my stories is only make-believe. [...] When violence is tied to fantasy and humour, children find it more amusing than threatening. (Dahl, qtd. in West Trust Your Children 75)

The violence in Robert Cormier's YA fiction has also been contested, most notably in The Chocolate War (1974) which has faced several censorship attempts in the US. About the use of contentious themes in his novels, including violence, Cormier has said:

There are no taboos. Every topic is open, however shocking. It is the way that the topics are handled that's important and that applies whether it is a 15-year-old who is reading your book or someone who is 55. (Qtd. in Gardner, "Robert Cormier")

There will always be children's books that challenge the boundaries of children's literature, especially as those with contemporary - and often contentious - themes have become more common. It is important that the voices of adults and children who speak for these books are heard as well as the vocal minority who question their suitability for children.

\section{The critical field}

In a career spanning nearly sixty years, Maurice Gee has written seventeen adult novels, two collections of short stories and thirteen children's novels. He is probably New Zealand's greatest living writer, but there are surprisingly no major critical studies on his fiction for children apart from two theses. This thesis addresses a gap in the scholarship. 
My framework for the thesis was informed primarily by Otto Heim's Writing Along Broken Lines: Violence and Ethnicity in Contemporary Māori Fiction, a critical study published in 1998. Heim organised his discussion on "expanding scenes of violence" (25) in Māori fiction under the headings of family violence, social violence, criminal violence and systemic violence. James Bertram, in his rather subjective essay entitled "Violence in New Zealand Literature" (1971), proposed four broad categories of violence: cosmic, natural, social and human (5). Conversely, Christina Jarvis identified five categories: personal, interpersonal, collective, institutional and global (Jarvis "Violence"). I have drawn from these three sources to develop the final frame for the thesis.

Bill Manhire's monograph, Maurice Gee (1986), is a small critical study mainly of Gee's early work for adults, prefaced by a useful biographical chapter. This chapter includes an explanation of Manichaeanism as it applies to Gee's work. Manhire's famous comment - that "[i]t would be wrong to subject Gee's work for children to the sort of close attention demanded by the adult novels" (11) - has been challenged by two recent theses on Gee's fiction for children. Diane Hebley's The Power of Place (1998) is a general study on place in New Zealand children's fiction up to 1989, and therefore only discusses The Fire-Raiser and The Champion, and then only in relation to drownings and rivers. In Leaving the Highway, Mark Williams' statement that "in Gee the violence springs from a level of the human mind that precedes the construction of social order" (174) was truly illuminating and enabled me to complete my discussion of Herbert Muskie and the shadow in The Fat Man. And the recently published A Made-Up Place: New Zealand Young Adult Fiction (2011), written by academics in the English Programme at Victoria University of Wellington, was a godsend towards the end of writing this thesis when I had despaired of finding any critical commentary on Gee's five historical novels. 
In relation to children's literature, Betty Gilderdale's comprehensive survey on New Zealand children's literature (“Children's Literature" 525-574) was a helpful guide as was J.A. Appleyard's chapter on "Later Childhood: The Reader as Hero and Heroine" (Becoming a Reader 57-93). Masculinity is an important theme throughout Gee's historical novels for children. In this respect, three books on New Zealand masculinity written by Jock Phillips (A Man's Country?), Kai Jensen (Whole Men) and Alistair Fox (Ship of Dreams) were also useful, with Phillips' book informing the sociohistorical description of family in chapter 3 of this thesis. Histories, too, were frequently consulted, including the generalist Belich's Paradise Reforged (2001), King's The Penguin History of New Zealand (2003), Mein Smith's A Concise History of New Zealand (2005), Eldred-Grigg's The Great Wrong War (2010) and Simpson's The Sugarbag Years (1974). Furthermore, Gee's autobiographical accounts were invaluable sources for chapter 1 of the thesis, as was his article "Early Reading", which outlines his (Gee's) personal philosophy: "I learnt that there is no help from outside, that a man makes himself or destroys himself" ("Early Reading" 25).

Three theses have provided valuable insights into Gee's historical novels for children and on puritanism. Louise Clark's excellent M.Phil. thesis, "Writing Vertically and Horizontally: The Relationship between Maurice Gee's Fiction for Children and Adults”, endorsed violence as a central theme across all Gee's junior novels (96). Vivien van Rij's $\mathrm{PhD}$, “The Pursuit of Wholeness in Maurice Gee's Fiction for Children”, is the thesis I wish I had written. It could not be more ample or more definitive on Gee and his children's fiction. Kirstine Moffat has also written a very clear and enlightening $\mathrm{PhD}$ thesis on "The Puritan Paradox", from which I have extended my knowledge of New Zealand puritanism. 
Interviews, articles, non-critical reviews and books have also provided me with useful background information. Judith Holloway and Agnes Nieuwenhuizen, for example, have both interviewed Maurice Gee about The Fat Man and from those interviews I have learnt more about the origins of the book and Gee's feelings about the controversy surrounding it. Newspaper articles, such as Marion McLeod's on The Champion, supplement Gee's autobiographical accounts while in R. H. Morrieson's The Scarecrow I have found clear links between Hubert Salter (The Scarecrow), Edgar Marwick (The FireRaiser) and Herbert Muskie (The Fat Man).

\section{Organisation of thesis}

This thesis is divided into four chapters. Chapter 1 establishes the impact of violence on Gee's early years and its likely influence on his writing. Chapters 2-4 consider the presence of violence in Gee's five historical novels for children. The novels are grouped thematically according to the form of violence being discussed in the chapter and then organised by date of publication in that group. Chapter 2 focuses on systemic violence in The Fire-Raiser and The Champion while chapter 3 explores individual, family and social violence in The Fat Man. The fourth and final chapter discusses the social violence that runs as an undercurrent of everyday life in Orchard Street and Hostel Girl.

This thesis begins, perhaps unusually, with a chapter outlining the influence of violence on Gee's formative years. Biographical readings are not in favour these days but I justify this one for the context it gives to Gee's writerly preoccupation with violence. 


\section{Chapter 1}

\section{Gee and Violence}

When Gee was asked if it was wrong to think we know him through reading his books, he replied: “No, I don't think it's wrong. [...] Obviously all my attitudes, beliefs, opinions, prejudices and so on get into the books. I couldn't prevent them from getting in if I tried because that's me and who I am" (qtd. in Hewitson "Maurice Gee"). While Gee's fiction for children generally contains much encoded biographical and personal detail about its author, there are more direct sources to establish his views on violence. This is why I turn now to Gee's accounts of his childhood to early adulthood, as well as accounts of those years from secondary sources, convinced that they offer revealing insights into the writer's preoccupation with violence in his historical novels. According to these sources, the young Gee was no stranger to violence.

\section{Beginnings}

Born in Whakatane in 1931 and brought up in Henderson, Maurice Gee was the middle of three sons from the marriage of Len $\mathrm{Gee}^{5}$ and (Harriet) Lyndahl Chapple. His father was a carpenter and his mother the daughter of James Chapple, a controversial socialist, rationalist and pacifist. As we shall see, from a young age Gee was someone who recognised the violence in himself and in others. This awareness of the dark side of human nature was balanced by a knowledge of its 'right' side through the rigid puritan values that he had been taught by his mother, values that his old friend Kevin Ireland said Gee had received "an extra basinful at home" (qtd. in Brett 96).

\footnotetext{
${ }^{5}$ Also known by his nickname 'Laurie'.
} 
Given what Gee has said and written about his childhood, it seems reasonable to assume that his view of the mixed, and often competing, nature of the human condition was shaped by the ideological contradictions within his own family - a working-class father with capitalist leanings who was handy with his fists and a creative middle-class mother who had a strong social conscience and an equally strong puritan ethos inherited from her family (“Beginnings" 286, Brett 95). As Gee's younger brother has confirmed, Gee took after his mother. He was a Chapple: puritanical by nature and puritanical by upbringing (qtd. in Brett 95). This had repercussions during Gee's adolescence and early adulthood when sex became a "guilty secret" because it transgressed his mother's teachings about the purity and holiness of the act (qtd. in Brett 96). Perhaps obliquely referring to himself, Gee has acknowledged that he has "always been aware of the way puritanism can cripple and destroy" (qtd. in Brett 99).

\section{Puritanism}

The puritanism Gee refers to arrived in New Zealand with the British settlers circa 1850 and still lingers today. Puritanism's origins were in the sixteenth century Protestant Reformation that sought to streamline and moderate forms of worship in the Church of England, its two forms "a body of theological principles" and a "secular code of conduct" (Moffat 4). For the Puritans the two forms were inseparable but by the mid-nineteenth century the latter's influence was greater and had become, for many in the Western world, the moral touchstone for the way life should be lived. In New Zealand's case, secular puritanism suited a way of life where Puritan values like hard work, thrift and self-reliance were essential for the colony's survival. By the 1950s it was regarded as the dominant social pattern in New Zealand by such writers as Bill Pearson and Robert Chapman (qtd. in Jones 455). More recently, academic Alistair Fox has added to the debate, claiming that 
"the impact of puritanism on the national psyche cannot be overestimated" (37). Although critics such as Kirstine Moffat and Nelson Wattie have argued that puritanism has antithetical elements (that is, both positive and negative), ${ }^{6}$ it has been more widely considered solely as a negative social influence, especially from the 1930 s to $1960 \mathrm{~s}$. H. Winston Rhodes sums up the anti-puritanism argument in this way:

It relies too much on a series of prohibitions. 'Thou shalt not' is more often used than 'Thou shalt'. Its morbid consciousness especially in relation to sexual impulses, fosters feelings of guilt for no valid reason and tends to destroy all reverence for warm physical life. Its heavy emphasis on the importance of work, irrespective of value, and its distrust of all forms of leisure that do not involve energetic muscular activity lead to an almost pathological suspicion of irregularity, of artistic endeavour and of happy-go-lucky non conformism. Conventional respectability and an ingrained materialism are disguised by outward forms of piety; and prudery becomes synonymous with virtue. (Rhodes $40-41)^{7}$

These prohibitions were enforced by mothers as moral guardians of the family, roles immortalised in literature in Bill Pearson's Mum Palmer (Coal Flat 1963) and Gee's own Mrs Prior (In My Father's Den 1972) and Mrs Rosser (Crime Story 1994). Sons especially felt the tension between doing what was 'right' and seeking the more exciting forbidden. Gee has depicted this tension in many of his male protagonists, notably the Prior brothers from In My Father's Den and Raymond Sole in Sole Survivor.

Gee has said on many occasions that the words 'creek' and 'kitchen' defined his childhood. In his 2002 Margaret Mahy lecture entitled "Creeks and Kitchens", 8 for example, he described the words as "the poles I moved between for most of my childhood. [...] They underline for me the essential duality that every writer must know:

\footnotetext{
${ }^{6}$ See Kirstine Moffat's “The Puritan Paradox" and Nelson Wattie's concluding comments in his piece on Maurice Gee in The Oxford Companion to New Zealand Literature, 199.

7 This summary of puritanism draws on Moffat 1-21; Jones, "Puritanism" 455-456; Wattie 199; and Fox 15-17, 37.

${ }^{8}$ This lecture is given in March each year by the recipient of the Storylines Margaret Mahy Award. The award recognises the significant contributions to the field of children's literature and literacy by the recipient.

Nominations for the award are invited and the winner is elected by members of the Storylines management committee. Margaret Mahy was the inaugural award winner in 1991.
} 
familiarity/mystery, safety/danger, dark/light, good/evil” (12). That essential duality is discussed next in relation to two other poles that I suggest Gee moved uneasily between from childhood to early adulthood: violence (in its many representations) and pacifism. The chapter concludes by discussing humanism, a non-religious ideology that Gee embraced as an adult, and its influence on the treatment of violence in his historical fiction for children.

\section{War}

Although Gee enjoyed a wartime childhood far removed from the harsh realities of war, he re-enacted a version of war's violence and partisanship every day. A fiercely patriotic boy, he was eight when World War II broke out and about 14 when it ended - formative years for a child. Gee's war, as it probably was for many boys of his age, was playing "violently anti-Japanese and anti-German games" with his friends and fighting with BB guns (Gee, qtd. in McLeod 29). It included a sinister game that involved burning old cardboard boxes in the backyard: "I used to imagine this was Hitler in his palace and I'd watch as the flames crept from room to room till there was only the last little corner of the cardboard box and Hitler was in there" (Gee, qtd. in McLeod 29). It is possible that Lyndahl Chapple Gee drew on her son when creating the character of Jackie in her short story "Double Unit". Like young Maurice, Jackie “played 'soldiers' constantly”. One of his favourite games was "realistically bayoneting and bombing Japs and Germans" (Chapple Gee "Double Unit" 25).

The English boys' weeklies and annuals with their stereotypical and jingoistic representations of war provided exciting reading for the young Gee. His hero was RAF pilot Rockfist Rogan from the weekly The Champion, a dare devil whose 'gung-ho' exploits he greatly admired: "Each week he'd shoot down a few Messerschmidts [sic] and have a boxing match. He'd generally get into trouble somewhere over Europe where he would be 
shot down and steal a German plane to get home again" (Gee, qtd. in McLeod 29). Finding an old World War I Chums annual at home, Gee devoured the imperialistic serials that dehumanised the enemy. He gleefully recounted the gory bits to his mother - the "trail of squashed Germans" and the "German gore" on the British soldier's bayonet - totally oblivious to any lack of humanity in his "dreadful glee" ("Creeks and Kitchens" 15). Her horrified reaction was, he recalls in "Creeks and Kitchens", "a lesson that stays with me still” (15) and may have provided him with his first inkling of war's inhumanity.

In fact, the closest Gee got to the real war was meeting the American soldiers his favourite aunt brought to the Gee home while her husband served overseas, accepting their gum and candy and playing 'Sink the Nazi Navy' with one of them ("Beginnings” 291). And, of course, spying with his friends on the American GIs and their girlfriends at Falls Park, "hoping to learn a bit about sex" (Gee, qtd. in McLeod 29).

Gee's war infiltrated his school life as well, where there were battles - physical, moral and patriotic - to be won. As historian Jock Phillips notes in A Man's Country?, boys at this time were encouraged to be tough and stoical, their role models soldiers and rugby players (258). So it would have been important for Gee to take the 'cuts' like a man and to be part of a rugby team that, in his own words, "trampled the nun-coached Cattle-dogs into the mud" ("Beginnings" 287). On the moral front, there was Gee's puritanical campaign in standards five and six to stamp out playground swearing as part of a "two-man purity squad" ("Beginnings" 288) that patrolled the playground listening for those who violated its code of linguistic propriety. In these two examples we can see the competing influence of both the masculine culture and his Chapple puritanism on the young Gee. 
Every morning Gee would patriotically salute the flag, sing "God Save the King" and march into school to military music played on a gramophone ("Creek and Kitchen" 89). The playground gangs were Army, Navy and Air Force and a favourite activity was swapping American cigarette packets. Once a week, there was an air raid drill when the children took cover in trenches especially dug for that purpose ("Beginnings" 288). Thus at home and at school, the young Gee glorified war, unaware of its harsh reality and the indiscriminate suffering it caused.

War influenced Gee's family life in ways he did not understand as a child ("Beginnings" 291), and may have exacerbated the ideological differences between his parents. There was the very real threat from the Japanese who were "spreading like yellow spiders down the Pacific" ("Beginnings" 291). Len Gee did not want to enlist but thought he should. He was on Manpower building gun emplacements to stop a Japanese attack on New Zealand. Gee remembers that "Dad was uneasy and quick-tempered in those years" ("Beginnings" 291). Showing different fears, his mother was worried that the war would not end before her boys were eligible to fight. Two of Gee's Chapple uncles had enlisted. ${ }^{9}$ One uncle, recalls Gee, "had wanted to be a conscientious objector but was not brave enough" ("Beginnings" 291).

\section{Masculinism}

On the home front, Len Gee was a powerful influence on his sons' perceptions of masculinity and violence, the latter seemingly a prerequisite for the former in line with the masculine culture of the day. While Lyndahl acted as a moral force who laid down the family rules, Len "put the practical and heroic" into his sons' lives ("Beginnings" 286).

\footnotetext{
${ }^{9}$ Lyndahl Gee's oldest brother, Leonard, had fought in World War I, rejecting his father's pacifism (Chapple, "Chapple, James"). This act of filial defiance is echoed in Plumb when Oliver, the oldest son of George Plumb, leaves for the Front (Plumb 141).
} 
From Gee's descriptions of his father, we get a picture of a tough and proud man who encouraged his sons to be like him; a man who was instinctively combative rather than peaceable; and a man who enjoyed placing a bet and drinking with his mates characteristics, indeed, of what Phillips sees as evidence of "the continued strength of the male culture" (Phillips 258) in New Zealand up to 1950. Len's sons believed he would fight people who crossed him, perhaps convinced by the time he had quarrelled with the butcher and "threatened to put his head in a tray with parsley in his mouth" ("Beginnings" 286). An ex-boxer, Gee senior thrilled his three sons with stories of his fights and knockouts - "the blood on the gloves, the deadly combination of straight left, right cross. We did our best to live up to him" ("Beginnings" 286).

That effort to live up to their father's expectations involved what could be called 'training' - rough play fights where his sons would give him 'the hammerlock and the Chinese burn until he howled for mercy" ("Beginnings" 286) and, in Gee's case, a humiliating fight with a much older boy (that his father watched and eventually stopped) where the foolproof "straight left, right cross" boxing technique his father had taught him failed and he ended up with chipped teeth and a swollen mouth. The boy probably learnt hard lessons that day about his father's fallibility and the invincibility of violence. ${ }^{10}$ No wonder he felt "[t]he world has gone lopsided" ("Creek and Kitchen" 84).

Gee gives two slightly different versions of this fight, one in "Beginnings" where his father stops the fight (286) and the other in "Creek and Kitchen" where it is his mother (84), which points out the frailty of memory. There is only a small relatively unimportant discrepancy between each account but it highlights the need to check facts carefully when dealing with autobiographical material. Memory can be an unreliable source given the

\footnotetext{
${ }^{10} \mathrm{He}$ also learnt that his mother was not always right: "I was right and Ernie Lisk wrong so I should have won. Isn't that the rule of life my mother teaches ...?" ("Creek and Kitchen" 84).
} 
mind's ability to create memories where none existed or to remember events differently to how they actually occurred. On the latter, Gee's (mis)recollection of seeing a man dive into Henderson Creek and break his neck (mentioned later in this chapter) is a good example.

Gee was very good at rugby, arguably a socially sanctioned form of violence, and played it to provincial level until he was twenty two. As he told Cate Brett, "[Rugby] was very important to me as a boy. I was living in this strange screwed-up world as an adolescent boy but I was also living a very manly life with the boys and it gave me a place where I could be a normal human being" (qtd. in Brett 96). No doubt the rugby playing contributed to what his younger brother, Gary, calls his enviable reputation at secondary school as a tough guy - that and "being very good with his fists" (qtd. in Brett 96). Interestingly, Gee possesses "the masculine credential of violence" (Jensen 165) that he gave his character, the ultra-masculine poet Rex Petley in Going West (1993). Gee had played rugby, been taught to box by his father and sorted out trouble with his fists. (There the analogy ends: Petley has a criminal record and goes on to murder.) Once again, in Gee's formative years, masculinity was aligned with violence.

\section{Corporal punishment}

Another kind of violence the young Gee experienced was corporal punishment, socially acceptable in those "heavily authoritarian" days (Gee, qtd. in Holloway 23) and administered as a corrective by parents and teachers. It also served as a painful reminder of the power imbalance between adults and children. Gee's paternal grandfather, who lived with the Gee family for a while, was apparently a die-hard about corporal punishment. As Gee recalls, "He was a tough old bugger, [...] always on about kids needing hidings. It was 
like a dose of medicine. A kid needed a hiding to smarten him up, set him right" (Gee, qtd. in Holloway 23).

Gee clearly remembers the corporal punishment he received at home and at school. He and his brothers got three big hidings at home for major transgressions. The boys would go to the bathroom and watch as their father cut a willow stick from the hedge, each vowing not to cry - but crying all the same: "That yellow stick raised welts like chains of mountains on our legs" ("Beginnings" 286). On his second day at school, Gee's teacher hit the palm of his hand with a ruler for supposedly taking a bite out of her apple. He denied it but was not believed ("Creek and Kitchen" 88). Years later, Gee still recalls the feeling of injustice. By the time he was in standard six, Gee appeared to have learned to repress such sensitive feelings. He acted tough when getting the "cuts", winking at his mates as he went back to his desk ("Beginnings" 287). In this way, Phillips might say, he was conforming to the expectations of the male culture that men were physically tough and indifferent to pain (Phillips 258).

\section{Physical violence}

Despite his mother's abhorrence of violence and her pacifist teachings, Gee seems to have recognised the human potential for violence, and, indeed, his own violent tendencies. Kevin Ireland implies that this self knowledge presented the puritanical Gee with a moral dilemma that plagued him for many years (qtd. in Brett 96, Hewitson 5). Thus the self-named "prissy child" (Gee, qtd. in McLeod 29) would sometimes metamorphose into the bully, the vandal or the villain. Young Moss ${ }^{11}$ had been a bully once, when he and his friends roughed up Fatty Walker for looking at the girls in the changing shed through a hole in the wall. This is

\footnotetext{
${ }^{11}$ Gee was called "Moss" or "Mossie" by family and friends.
} 
something Gee admits to being ashamed about, even at the time: "Our rage was made up of moral indignation and bitter envy. Fatty had done what we longed to do. We punched him without mercy and his blubbering fulfilled us" ("Beginnings" 288).

Then there was the time when the Gee brothers wrecked the nearby Catholic school, upturning inkwells, ripping up books and pictures, tearing down maps, breaking the chalk and putting drawing pins on the nun's chair. It was full-scale vandalism based on their irrational hatred of the nuns whom they thought of as "witches" who were "sinister, dangerous" ("Beginnings" 286). For that act of violence, they were punished severely: "We went to the bathroom and watched while Dad cut a willow stick" ("Beginnings" 287).

Other physical acts of violence occurred in different places, usually in the company of other boys. Some may be attributed to a youthful testing of the boundaries between 'allowed' and 'forbidden'; others to an adolescent perception of what being manly meant. The young Gee was guilty of cruelty when he and his brothers set out mousetraps to catch the sparrows at his grandparents' place, and were punished when they caught the sparrow Grandpa Chapple had tamed ("Beginnings" 285). And again, at Henderson Creek when he and some friends "murdered" eels, all the while knowing "a kind of horror [...] at what we were doing” (“The Way" 40).

Not only had Gee acted violently on many occasions as a child and adolescent, he had also witnessed or heard about violent acts and been in places where violence lurked. $\mathrm{He}$ recalls being there when a man broke his neck diving into shallow water at Henderson Creek and died from his injuries ("Creek and Kitchen" 89). However, by checking newspaper reports of the time, Gee's biographer, Rachel Barrowman, has found this to be a false memory ("Writing Lives"). Gee knew that the creek with its deep dark pools, huge 
eels and slippery rocks was a dangerous place where people could drown. It was a place where he had nearly drowned himself ("Creek and Kitchen” 12). A boy he knew had a dog that skinned hedgehogs alive while his father watched and, in the Chapple family itself, an aunt had chased her husband through their orchard wielding an axe ("Beginnings" 285). ${ }^{12}$

\section{Literary violence}

Three authors confirmed Gee's views about the human condition and its propensity for violence - Zane Grey, then Charles Dickens and, later, Ronald Hugh Morrieson. At fourteen, Gee read twenty five Zane Grey novels within six months, swallowing them in "one barbaric gulp" (Gee, qtd. in Nieuwenhuizen 5). Grey may have been a formulaic writer but he underlined truths the adolescent Gee already seemed to know about human beings and probably introduced him to the secular humanist belief he holds today:

With [Grey's] aid I was able to take my first long look at 'the human condition'. I saw that human beings are lonely, that they lose what they most desire, that the passions that shake them produce cruelty more frequently than kindness. Most important, for one brought up in a non-religious household, I learned that there is no help from outside, that a man makes himself or destroys himself. (Gee, "Early Reading” 25)

Zane Grey prepared Gee for Dickens whom he rates as the novelist who changed his life and readied him for writing. And so, at sixteen, Gee read his way through Dickens: "I entered that huge and violent and tragic and heroic and comic and swarming world of the imagination, the Dickens world, and I haven't come out of it since" ("Creeks and Kitchens" 17). Through reading Dickens, Gee says he gained a broader view of the dark and light side

\footnotetext{
12 The latter incident has a tragi-comical reprise in Gee's adult novel Sole Survivor (1983) where a daughterin-law of George Plumb, Mirth, chases her husband, Willis, through the family orchard with a carving knife, threatening to castrate him because of his latest infidelity (Sole Survivor 42-43).
} 
of human nature: "He put me in a moral universe. He taught me about good and evil" (“Creeks and Kitchens" 17).

Later, the adult Gee would read Morrieson's The Scarecrow and call it "a terrifying comic masterpiece" (qtd. in "Gee, Maurice"). He would go on to create violent characters like the eponymous Edgar Marwick (The Fire-Raiser) and Herbert Muskie (The Fat Man) in his historical novels for children but temper them with a humanity denied Morrieson's Hubert Salter. ${ }^{13}$

\section{Pacifism}

Jostling with Gee's awareness of violence as part of the human condition were the pacifist ideals he inherited from the Chapple side of his family. These ideals will be discussed later in this section, but first an overview of New Zealand pacifism during World War I and World War II is necessary.

Pacifists were treated harshly in World War I. They were considered shirkers, nonpatriots and cowards for refusing to fight. Many people believed they should be forced to fight or be imprisoned. The Government view was unequivocal: "In wartime a major duty of citizenship was defence of country. If a man refused to undertake this, the State had a right - and a duty - to force him to do so or to deny him the privileges of citizenship. In doing so it was operating not despotically, but in the common good" (Grant Field Punishment 18). Conscription was introduced in November 1916. By the end of the war, only seventy three conscientious objectors had been exempted. The main reason for this appears to be the very narrow definition of a genuine conscientious objector in the

\footnotetext{
${ }^{13}$ See chapters 2 and 3 for more detail on the links between Marwick, Muskie and Morrieson's Salter.
} 
legislation. In practice this meant only Quakers, Christadelphinians and Seventh Day Adventists were exempted (although they were still required to do non-combatant service).

Those conscientious objectors who had been denied exemption (over 100 in 1917) were sent to prison and subjected to a tough regime aimed at breaking their resistance. Those who did not give in were court martialled and sentenced to hard labour for one to two years. Amongst the latter were Archibald Baxter, who had objected on ethical grounds, and Mark Briggs, a political objector. Baxter had long held the view that "war - all war - was wrong, futile, and destructive alike to victor and vanquished" (Baxter 9). In mid-1917, it was decided to send all objectors to Europe as 'soldiers' on completion of their first sentences. If they remained defiant, they would be punished until they submitted. On 14 July the first group of objectors, fourteen in total, was sent to the Western Front. Baxter and Briggs were in that group.

Initially based in camp near Salisbury, the men were exposed to a range of humiliating and barbaric punishments. Three of them gave up at that stage and one was discovered as having been wrongly denied exemption status. In France, the inhumane treatment continued and three others submitted. Out of the seven who remained steadfast, three received hard labour after being court-martialled. Their spirit broken from brutal treatment in prison, these three men became stretcher bearers. The other four, including Baxter and Briggs, were subjected to further cruel treatment and privation, including Field Punishment No. 1 (commonly known as the Crucifixion), and being sent into the trenches. Only Baxter and Briggs held out to the end of the war, when both were invalided back to New Zealand. Baxter had been diagnosed as insane and Briggs as unfit for active service. Their determined resistance had earned respect for them personally and their cause. 
Baxter's moving account of his experiences in World War I, We Will Not Cease, followed in 1939.

While conscientious objectors were treated more humanely in World War II (they were not forced to become soldiers as had happened in World War I), the government approach to them was still punitive. About eight hundred were held in detention camps until the end of the war and others, key pacifists like Archie Barrington and Reverend Ormond Burton, received stiff jail sentences for subversion. Burton was a World War I hero who had converted to Christian pacifism shortly after the war, becoming a Methodist minister in the mid 1930s. His A Testament of Peace, published in 1940, announced his intention to base his preaching on "a pacifist doctrine of worship" (qtd. in Grant "Burton") despite an earlier ruling from the Methodist Church that the pulpit was not to be used to encourage or resist military service. In 1942, Burton was expelled from the Methodist Church for defying the church's ruling. ${ }^{14}$

However, someone closer to home than those well known World War II conscientious objectors was Gee's role model for pacifism - not his pacifist mother or his grandmother who hated "warmongers" ("Creek and Kitchen" 90), but his grandfather, a radical pacifist and socialist who had controversially lectured against war and been imprisoned for sedition (Chapple "Chapple, James"). James Chapple's influence on the Gees was pervasive. As Gee recalls, “[w]e were Labour, we were pacifist. It was something I knew, not something I understood. Beliefs came from Grandpa Chapple. I had not taken in his story but I knew his hand was on our family" ("Beginnings" 290). But that hand was not always welcome. Gee says it caused tension between his father, a realist who saw the flawed human in his father-in-law ("Beginnings" 290), and his mother, who saw

\footnotetext{
${ }^{14}$ This summary of New Zealand pacifism during World War I and II is drawn from Taylor 171-208, Grant Field Punishment No.1 7-91, and Grant "Burton".
} 
only the principled idealist in her father and tried to emulate him in her own life (Gee, "The Way" 41). For his part, Gee found the hero and rebel in his grandfather from his mother's stories of him, not in the man himself:

[His] days on the West Coast as a Presbyterian Home Missionary; as a minister of a church in Eltham, where he quarrelled with his parishioners over the 'sweated labour' of children in milking sheds; his quarrel with the church over evolution, his resignation and his anti-war lecture tours and imprisonment for seditious utterance. I found it all heroic (I still think it brave) and my grandfather became a major figure in my life. Because of him, because of his career, I believed for a long while that one can be sure of Right and Wrong and find a Way. This [...] was as close as I came to a religious education. ("Creek and Kitchen" 91)

Grandpa Chapple's pacifist ideals must have provided the young Gee with an awareness of the potential for good in human nature. They may also have allowed him to harness the violence in himself as he grew up. Yet how to reconcile the hero with the little elderly man in sandshoes and suit who was hard of hearing? As Gee has said, "[...] I had two beings, the hero and the man, who would not overlap and I began to make hard judgements on my grandfather" (Gee, "The Way" 41). Grandpa Chapple cheated at draughts ("Beginnings" 290), dithered over whether it was cruel to drown a rat found in the house ("Creek and Kitchen" 92), and showed a mercenary side in demanding retribution in stamps, not the terrible punishment expected, when his grandsons killed his tame sparrow (Gee, "The Way" 41). He had also been a harsh disciplinarian, physically punishing his own children when they had misbehaved (“Creek and Kitchen” 90).

Over time, Gee says he replaced the hero with the man and his mixed human nature but retained the ideology he espoused. Unsurprisingly, then, when Gee started writing his first novel at seventeen it was a pacifist one: "I wrote five or six chapters of a novel that was supposed to make war impossible for all time. That's a proper ambition for a boy of seventeen" (qtd. in Boyd 160). Even though he did not complete the novel, it was born out 
of the ideals he learned from his grandfather. Years later he would incorporate those pacifist ideals into his historical novels for children.

\section{Humanism}

Maurice Gee is a self-confessed "atheist humanist" (qtd. in Smithies "Maurice Gee") and an Honorary Associate of the New Zealand Association of Rationalists and Humanists ("NZARH Honorary Associates"). Humanism is defined by the NZARH as "a belief that humanity itself matters far more than supernatural beliefs and that the best morals stem from an examination of humans and their needs rather than a blind belief in religious dogma" ("Secular Humanist Morality"). NZARH members endorse the principal objects of the organisation, namely, "to advocate a rational, humane and secular view of life without reference to supernatural agencies and which is compatible with the scientific method; to promote a tolerant, responsible and open society; and to encourage open-minded enquiry into matters relevant to human co-existence and well-being" ("About the NZARH"). Acceptance of these objects is a condition of membership.

Humanism is not a religion. But Gee has acknowledged that something like an animistic religion once operated in his childhood relationship with his grandfather: "He was a kind of powerful spirit and just as the nuns moved in darkness he moved in light" (Gee, "The Way" 41). Today his strong ethical beliefs are based on a secular humanist morality not too far removed from the radical socialist views his free-thinking grandfather held, ${ }^{15}$ and which alienated him from the conservative religious community during his lifetime (Chapple “Chapple, James”).

\footnotetext{
${ }^{15}$ In James Chapple's day, terms like "free-thinker", "secularist" and "rationalist" described what we would now call a humanist ("Pamphlet of Humanism in New Zealand").
} 
As Peter Beatson has observed, “[t]he ghost of Original Sin haunts Gee's world, though in a secular form where biology has replaced theology as the explanation for the Fall” (Beatson "Maurice Gee"). Biology, in fact, was exactly the basis of James Chapple's argument when he controversially preached evolution rather than creation as a Presbyterian minister circa 1907 ("Creek and Kitchen" 91). It appears, then, that the beliefs of grandfather and grandson are ideologically similar.

If we look at the history of the Presbyterian Church in early twentieth century New Zealand, we can see that it was an influential but conservative organisation. This conservatism (especially in theology) would explain the reaction of the Timaru presbytery to James Chapple's unorthodox views on socialism and creation. Laurie Barber notes that at this time the Presbyterian Church was a national church with authority vested in a centralised General Assembly and an all-male membership comprising ministers and elders voted in by their presbyteries. In 1906 nearly $23 \%$ of the New Zealand population was Presbyterian, $45 \%$ of these living in the south of the South Island. The church effectively had a two-tier ministry aimed at serving all of New Zealand. University-trained ministers were appointed to parishes and, because there were more parishes than ministers, a "mixed bag" (Barber 82) of untrained home missionaries offered pastoral care in large and rural areas. James Chapple was one of these home missionaries, serving in Kumara (south of Greymouth) between 1898 and 1901.

Within the parishes the church demanded compliance, not only over church attendance but also parishioner behaviour. The breaking of the Sabbath was sternly denounced. Presbyterian leaders believed they had a responsibility to correct community morals as well and did so for sins such as Sabbath breaking, drinking and gambling. 
Solemn sermons repeated the established theology to equally solemn congregations. Roman Catholics were considered heretics and Church of England parishioners suspect. ${ }^{16}$

This was the church that James Chapple served from 1903 to 1910, as a minister at St Andrews near Timaru. Over this time the Timaru presbytery made several attempts to remove him from office because of his unorthodoxy. According to Geoff Chapple (Chapple's grandson and cousin of Maurice Gee), James Chapple faced eight charges of transgression in a public hearing held in September 1910 ("Chapple, James"). The charges included preaching in support of the working class and protesting "against the absurdities of the orthodox teachings of the present day" (Chapple "But Earth"). Chapple did not resile from his actions, and so the presbytery resolved that he should resign from his post at St Andrews and from the Presbyterian Church. This Chapple did, having thought for some time that he was "a square peg in a round hole" (qtd. in Chapple "Chapple, James").

Gee's humanist beliefs almost certainly had their origins in his childhood, along with his ideas on violence and pacifism. Most probably those beliefs grew out of Grandpa Chapple's political socialism which was, at its extreme, "public support for the advance of Soviet communism" (Chapple "Chapple, James"). So it is no surprise that Gee's favourite book as a child was a collection of Robin Hood stories about which he has said: "[ [...] robbing from the rich to give to the poor, that really appealed to a boy growing up in a family leaning strenuously to the left" ("Creeks and Kitchens" 15). Nor is it a surprise that today he describes his politics as "a natural lean to the left" (qtd. in Smithies "Maurice Gee") or that much of his fiction generally has underlying social, political and environmental concerns.

\footnotetext{
${ }^{16}$ This summary of the Presbyterian Church in early twentieth century New Zealand is drawn from Barber 74-87.
} 
What may be unexpected, however, is the often symbiotic relationship between humanism and violence in Gee's fiction for children generally. By setting characters with humanist values like social responsibility, rationality and kindness against those with violent traits, Gee exposes the trumpery of violence and offers an ethically viable alternative to it. Without that humanism, the violence might be seen as privileged; without that violence, the humanism might be seen as moralising. Beatson, in discussing Gee's work for adults, aptly notes that the writing "leavens cruelty with sympathy" (Beatson "Maurice Gee"). That leavening of complementary opposites - one associated with the violent and the other with the humane - acknowledges the mixed nature of the human condition that the young Gee appeared to instinctively recognise and which he would replicate in his historical novels for children. Bill Manhire describes this view of the human condition as "essentially Manichaean" (Manhire 11), that is, a belief that there is a conflicting dualism between the evenly matched forces of good and evil in people and in the world in general. Hence the name 'mixies', which Gee gives to the humans in the $O$ trilogy and which applies generally to the characters in his children's fiction.

While violence was clearly part of Gee's childhood and adolescence, so too was the tempering influence of pacifism. New Zealand's masculine culture and secular puritanism also exerted their competing pressure on Gee as he was growing up. As the following chapters will demonstrate, these influences would become recurring and interlinked motifs in his historical novels for children. Similarly, the humanist beliefs adopted by Gee as an adult would become a moderating force in his treatment of violence for that same audience. 


\section{Chapter 2}

\section{Systemic Violence and the Wartime Novels}

The publication of Gee's two wartime novels, The Fire-Raiser (1986) and The Champion (1989), marked a return from his earlier children's fantasies to the critical realism of his adult fiction and his engagement with the past. These novels were the first two of Gee's five historical novels for children that, to paraphrase Harry Ricketts, offered an unauthorised and fictionalised version of recent New Zealand history (80). Both books started off as successful 'kidult' television series screened by Television New Zealand in 1986 and 1989 respectively. ${ }^{17}$ Gee wrote the screenplay for each series. He had written for television before. It paid well and, along with writing for children, fitted in with his plan to "widen my range and try to be more commercial" ("Creeks and Kitchens" 17). Writing "the book of the television series" (as the book cover of each novel stated) fitted the plan too, and so Gee turned his television scripts into two children's novels with the same titles as the series. The Fire-Raiser became the starter for Gee's adult novel Prowlers (1987), which followed the lives of Kitty, Noel, Irene and Phil into adulthood.

In many respects, The Fire-Raiser and The Champion are complementary novels. Their settings are small towns similarly shadowed by war - World War I and World War II - and their stories about the impact of these events on ordinary New Zealanders. Their themes address some of the issues of each period (and contemporary issues too, by association) but without the angst associated with a contemporary problem novel because events are safely distanced from junior readers by time and place. This distancing effect seems especially important in the historical novel for children that deals with challenging themes. As Bärbel Czennia observes in relation to the historical novel: "Its medium-sized

\footnotetext{
${ }^{17}$ I viewed the videos of both series at TVNZ Archives: The Fire-Raiser (TVNZ Archives: ZFIRE-01-01-05. Eps. 1-5.) and The Champion (TVNZ Archives: ZCHA-89-01 to 06. Eps. 1-6.)
} 
temporal distance to traumatic events provides a buffer, big enough to make an imaginative approach emotionally bearable, yet not so big as to overlook the living continuity between past and present" (71). Other forms of distancing can also provide the emotional buffer Czennia refers to. Third person narratives such as used in The Fire-Raiser allow the often necessary distance between a novel's themes and the reader in historical fiction for children and avoid the problem of over identification with the 'I' in first person narratives. History itself may be distanced in the historical novel as the author re-envisions the past and, importantly for this thesis, the violence implicit in historical narratives may be neutralised by its remove from the young reader's world.

This chapter focuses on systemic violence in Gee's wartime novels, specifically war and racism. About systemic violence in contemporary Māori fiction, Otto Heim says:

All violence is political insofar as it is related to problems of the distribution of power and the way this affects people's sense of embodiment [...] We can, however, also speak of political violence in a narrower sense, designating forms of violence that occur in more or less public antagonisms over the right or capacity to shape society, where the individual participants are either themselves political agents, or, more often, actors sponsored by some politically interested agency. (Heim 125)

It is under this narrower sense of political violence - that which Heim calls systemic violence $^{18}$ and applies to violent antagonisms such as terrorism, sabotage and war found in Patricia Grace's Potiki (1986) and Witi Ihimaera's The Matriarch (1986) - that I place the two forms of violence considered in this chapter. Heim defines war as "violence of the most systemic process of destruction" (125) but it is important to note that it is a sanctioned and orchestrated violence. He does not specifically mention racism under his category of

\footnotetext{
${ }^{18}$ Peace researcher Johan Galtung places violence into three overarching categories: direct, structural and cultural. In his schemata, war would come under direct violence and racism under structural violence. (See Galtung's Peace by Peaceful Means, 196-210.) While Heim's schemata is not complete (being limited to family, social, crime and deviance, and systemic violence), I have preferred it here for ease of discussion in this chapter. Heim's category of systemic violence is a 'broad church' that includes both war and racism.
} 
systemic violence but I justify its inclusion here by its potential to create "public antagonisms over the right or capacity to shape society" (Heim 125). This potential is implied in Paul Spoonley's definition of contemporary racism as "an ideology of racial superiority in a situation where the holder has some power" (4). In other words, says Spoonley, "prejudice plus power denotes the racist in the modern sense" (4). My discussion begins with The Fire-Raiser, where I argue that the story can be read as an allegory of war.

\section{The Fire-Raiser}

The Fire-Raiser tells the story of an arsonist whose actions threaten the small town of Jessop and the children who bring him to justice against the odds. The year is 1915 and local events in Jessop take place over about two weeks, from 23 March when Dargie's Stables are set alight to an estimated 7 April when the fire-raiser is apprehended. This compressed timeframe shapes and propels the novel's central narrative. Framing the story are the real events in the Balkans, Caucasus and on the Western Front, which help to provide its historical authenticity and support its anti-war message.

\section{Sources and influences}

According to Gee:

The idea for The Fire-Raiser began when I wrote a history of the local school and came across one of the early headmasters - an outstanding character in Nelson's history. Then there was a brick-layer who was a fire-bug. He claimed at his trial that he burnt down buildings to make work for the unemployed. So I had these characters almost ready-made and mixed some children in with them to create the story. (Qtd. in O’Brien, “Making Sentences Work” 113) 
The history Gee refers to is his Nelson Central School: a History which was published in 1978 to commemorate Nelson Central School's centenary. It draws on local historical sources including newspapers, photographs and first-hand accounts of the time and its people. As such, it is a valuable source for the novel. His two "almost ready-made" characters are Johann Blecher, the Nelson fire-raiser of 1892 to 1894 and F.G. Gibbs, a headmaster at Nelson Central School from 1894 to 1923 (History 32-33).

Gee decided to set his story in 1915 during a formative period of New Zealand history:

I updated the story to 1915 because I thought it would be interesting to look at the anti-war and anti-German feeling that developed [...] the hysteria and jingoism. I also had a handwritten copy of an old patriotic pageant that must have been performed around Auckland schools in about 1915 or '16 and I wanted to try my hand at something of that sort. I found that in a box of old papers in a library I worked in once. (Qtd. in Jenkin 19)

These sources - Gee's History and the primary school pageant - have played an important part in developing the novel's main theme of war. Gee is also likely to have consulted contemporary histories such as Keith Sinclair's revised edition of A History of New Zealand (1980) and to have read fiction and non-fiction about World War I by writers such as John Mulgan, Archibald Baxter and Robin Hyde. Condliffe's A Short History of New Zealand (1925) and The School Journal may have been useful historical sources, too. Certainly, The School Journal, first published in 1907 and made compulsory in schools in 1914, perpetuated the jingoism of the war period well into the 1930s (O'Brien A Nest 8, 14, 16).

Gee wrote The Fire-Raiser in the mid-1980s and those years have also had an influence on the novel. Significant at that time was the continued weakening of New 
Zealand's traditional links with Britain, a situation explored in the novel in terms of postcolonial concerns about imperialism and nationalism. Advances in gender equality in the mid-80s may be seen in the novel's 'unladylike' Kitty who is clever, noisy and sporty. And national identity, which was being redefined in the mid-1980s at Anzac Day commemorations, is being formed in Gee's novel by practical men like Hedges and baker Wix. ${ }^{19}$

\section{Representations of war}

War pervades Jessop. Drawing particularly on the research for his school history, Gee adds a factual dimension to his story that strengthens its theme of war. Nancy, the Chalmers' maid, wants to work in a factory and Phil watches recruits leaving on the train for Trentham Camp. The local newspaper carries reports about the progress of the war (the landing in the Dardanelles, the capture of Neuve Chapelle, the Fall of Przemysal and the bombing of the

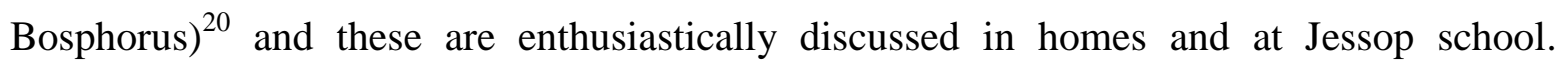
Headmaster Thomas Hedges, like the real F.G. Gibbs on whom he is based, turns reports of the war into geography lessons, plotting its progress with flags on a wall-map in the classroom. Mrs Wix knits socks for the soldiers and Mrs Chalmers donates money to the Belgian Relief Fund. Echoing Gibbs' Standard Six class, Hedges' class sings patriotic songs that reinforce the militancy of the day (Gee, History 28-57). In this way, then, the novel presents a realistic version of small-town life in New Zealand during World War I.

But war also has an allegorical presence in Jessop. Hedges explicitly makes a connection between the international conflict and warring factions in Jessop when he

\footnotetext{
${ }^{19}$ See Mein Smith 201-225 on the 1980s in New Zealand.

${ }^{20}$ The dates of these events precede the timeframe of the story but would probably been reported during that time. The action in the Dardanelles occurred between 25 February and 18 March; the battle of Neuve Chapelle took place from 10-13 March; Przemysl fell on 22 March and the Russian were bombing the Bosphorus around 18 March ( Duffy "Timeline").
} 
suggests (hypothetically) that if he and Lotte were to hate each other on the basis of their nationality we would " have a little war in Jessop to go with the big one overseas" (106). This sets up the possibility that what is played out in Jessop over the course of the story is in fact an allegory of war, or at least an allegory of the psychology of war, that begins with Marwick's fires and culminates in the mob attack on Lotte Stauffel's house. Taking the argument further, it may be that the moral defeat of the 'allied forces' in the town, albeit after wreaking extensive damage to Lotte's property and possessions, anticipates the massacre of the Allies at Gallipoli and a changing world for the children and New Zealand. Phil appears to intuit this: "[I]t seemed as if a huge wheel was turning and would not stop. He seemed to hear the rumbling sound it made and a cracking of bones under its rim" (135). In what follows, we will see that the behaviour and language of war is echoed in the novel's characters and their actions.

The fires

Marwick's fires are attacks under cover of night on the town's key sites of business and community - stables, warehouse, church and school. They consume and destroy, as would fiery attacks of a military kind on towns like Neuve Chapelle and Ypres in the big war overseas. At Dargie's Stables, "Flames ran like snakes. [...] Horses reared and screamed in their stalls" (9). The fire becomes a monster, devouring all in its path. The flames "poured everywhere, and were like a wind at the same time, slapping and thumping, puffing and beating. In the end they turned into a throat, gulping roof and walls" (14). If the fire is a voracious monster so too is war with its insatiable appetite for death. Gee seems to imply that whether caused by an arsonist's fire or soldiers' gunfire, destruction and suffering are the result. 


\section{The peacemaker and the soldier}

Hedges and Marwick are antitheses. In Jungian terms they may be seen as two halves of a warring psyche: the ego and the shadow. As the ego, Hedges plays the part of peacemaker in Jessop and as the shadow, Marwick plays the soldier at war with the town. ${ }^{21}$ Pacifist Hedges works to restore harmony between children, between parents and children, and between Jessop's institutions. Although he enjoys the art of war, (that is, the strategising) Hedges is unequivocal about the killing: "Men are dying out there. Thousands of them. All because we haven't got control of what's in [our heads]" (109). Marwick, however, has nothing but fire in his head as, soldier-like, he invades Jessop at night: "The town seemed hostile, like a fortress" (66). Yet he breaks through its defences to take first Dargie's Stables and, on another night, Chalmer's warehouse. Vivien van Rij also sees the soldier in Marwick, quoting his "hooked finger salute", "balaclava" and progress through Jessop as if in a "war zone", as well as his assumption of military command over the mob: "Enough talking, boys. Follow me" on page 44 of her thesis. Both these roles - peacemaker and soldier - have parallels in the larger theatre of war, and serve as emblems of war.

\section{Jessop's local war}

Jessop symbolically re-enacts the overseas conflict every day. It is a combative town and words of combat riddle the text. Its citizens wrestle, squabble, battle, quarrel, bully, argue, fight, slap, threaten, smack, knock down, kick and incarcerate. At all levels of Jessop society from the lowly Phil Miller to upper class Mrs Marwick, there is conflict that is settled or escalated with fists, angry voices, corporal punishment or threats of imprisonment.

\footnotetext{
${ }^{21}$ Gee's Edgar Marwick may owe a debt to R.H. Morrieson's Hubert Salter. Both characters represent the dark side of their town's psyche - the shadow - and are associated with similar imagery. Marwick was "the thing that flapped and loomed like a huge bird [...] running on the road" (The Fire-Raiser 13) while Salter was "a shadow, like that of a huge bird, stumbling across the tracks into the gloom" (The Scarecrow 35).
} 
Children experience repeated physical and verbal abuse by parents and others in positions of authority in the town. Bullying of the small and vulnerable occurs at school, and is not just restricted to children bullying children. Anglophile Mrs Bolton bullies the children into doing the pageant and throughout rehearsals to performance night. Phil is a particular target because of his low social status (and his "navvy" (59), that is, New Zealand pronunciation of 'white' as 'whoit'). ${ }^{22}$ The teacher's bullying is reminiscent of Germany's treatment in World War I of small countries like Belgium and expressed (in hyperbolic language) by Noel as the Kaiser in the school pageant: "I shall tear this poppy Belgium from her stem. My heel shall grind her petals in the mud" (115). Bullying, physical abuse and sexism are condoned by the institutions of Jessop (church, school, town hall) and the higher echelons of authority (the government, through its xenophobic and sexist MP, Jobling).

Within this volatile setting of class, gender and ageist conflict, nominal allies and foes form within the town. Mrs Bolton and Reverend Wilmott, for instance, are establishment allies, their foe Hedges and his non-conformist beliefs. The troika of mothers, Marwick, Chalmers and Bolton, form an imperialistic phalanx against their main rivals, the outsiders Lotte Stauffel and Hedges, while self-satisfied authority figures such as Sergeant McCaa and Mayor Chalmers join forces to undermine the children. But the main grouping is that of the Marwicks against Hedges and his supporters, including the children. While we might expect this local 'war' to understudy the conflict overseas, it is in fact a battle much closer to home - Empire versus Dominion. Imperialism has been imposed from Britain and sits uneasily in its adopted country. That the Marwicks are pitted against Hedges' troops and are defeated seems to be prophetic, suggesting the demise of an outmoded imperialism and the rise of New Zealand nationalism. Erin Mercer argues in similar terms:

\footnotetext{
${ }^{22}$ Ironically, by the end of the novel it is Phil out of the four child protagonists who best represents the emerging New Zealand identity.
} 
The threat to Jessop is [...] the power of socio-political structures based on outmoded systems of knowledge. Conquering this threat involves rejecting the superstitions of the past and championing a rational future for New Zealand identity free from the influence of Empire-touting pedants with "plummy" (111) accents. (Mercer 34)

On a human level, however, Gee shows that victory has been achieved at the cost of Marwick's sanity and his mother's near drowning. The children must take some responsibility for their part in this and for their relentless pursuit of the man with his mind "full of flames" (25). Some compassion for the Marwicks is due and Gee invites this from his characters and young readers by allowing an insight into what has motivated their behaviour. Marwick has been "damaged in ways that could not be repaired" (39) by his mother's cruel treatment of him as a child, locked for periods of time in a cupboard as punishment for not preventing his sister's drowning, while crazy Mrs Marwick has never got over the death of her beloved daughter. Kitty can empathise with Mrs Marwick:

[Kitty] lay on her bed and thought of Mrs Marwick in fine dresses, at garden parties, and thought of her now, in the parlour with the photographs everywhere and the yellow scales on the piano, and felt very sad, and frightened too, at the danger and dreadfulness of life, and the mystery of time passing by and making things old, and things that happened long ago staying alive and turning people into different shapes. (The Fire-Raiser 102)

As members of the English upper class, the Marwicks have enjoyed a privileged life in New Zealand. Fallen on hard times and withdrawn from society, Mrs Marwick and her son effectively become outsiders in Jessop. Their resistance to social change (and a new order where citizens' rights count more than birthright) puts them in conflict with the community, especially over riparian rights now vested in the town. Gee, of course, is using a 1980s explanation here for the Marwicks' abnormal behaviour. Psychology, says Hedges 
in the novel, was "a brand new science" (25) in 1915. Nevertheless, in what is a consistent approach throughout his children's novels, Gee reveals the humanity in his flawed characters as if to remind us that as 'mixies' the potential for evil is in all of us.

It is interesting to speculate on what happened to Marwick at the end of the novel and whether we can draw any parallels between his likely punishment (as the enemy in this story) and that of Germany's (as the big enemy in World War I). Presumably Marwick's punishment was prison, not treatment. Germany, on the other hand, faced the punitive terms of the Treaty of Versailles. Marwick's antecedent, the historical Blecher, was imprisoned for four years with hard labour (“Criminal Sittings" 3).

\section{$\underline{\text { Lotte's persecution }}$}

German widow Lotte Stauffel's persecution by the town mimics Germany's persecution of the countries it invaded in World War I and, the obverse, the historical persecution of Germans in New Zealand at that time. As Stevan Eldred-Grigg notes, anti-German sentiment in New Zealand during World War I was widespread. Classified as 'aliens', Germans or those of German extraction suffered many restrictions on what they could do and say. Some were sent to camps or interned on Somes Island while others lost their jobs or had their livelihood threatened by boycotts and vandalism (Eldred-Grigg 114-115, 167-173). In the novel, kind Lotte is regarded as a Hun, 'the other', and so as representative of her race. Anonymous Jessop citizens thus make her a scapegoat for all German activities in the war overseas and vent their hatred with actions of increasing intensity, from throwing stones on her roof to writing "Dirty Hun' on her front door. That Lotte becomes 'the other' is ironic as she appears to have been living peacefully and independently in Jessop for some time, earning her living as a piano teacher. The fact that she is well established in the town 
is shown by the brass plate on her front door that says 'Lotte Stauffel, Pianoforte' and her regular pupils, who include Kitty and Irene. Further to this is the easy familiarity of the relationship she has with Hedges, one that seems to be longstanding and serious.

Fuelling the xenophobia about Lotte is her appearance as a stereotypical German frau. She is "lovely plump Frau Stauffel, with apple cheeks and pixie chin, blue-china eyes, and a mouth like pink icing smoothed with a knife" (44). Her mannerisms and accent further mark her as foreign. Steeped in the sophistication of all things European (art, music, food, literature), Lotte stands out in Jessop and shows up New Zealand women - those like Mrs Wix who might feel they "would be better employed milking cows or shoeing horses" (101), and those like Mrs Chalmers "playing ladies" (48) - and New Zealand culture as dull. In this sense Lotte is more civilised than her persecutors, not just as an individual but as a European. European history is long and illustrious, compared with the short history of postcolonial New Zealand. Perversely, as Hedges' wife, Lotte is likely to be accepted by those who have threatened her because she is German - her marriage will be seen as a sign of integration.

\section{The patriotic pageant}

The patriotic pageant performed by the children of Jessop school resonates as a metaphor of World War I. Gee based this pageant on the text of a World War I primary school pageant that he had found in a library he had worked in ("Creeks and Kitchens" 21, Jenkin 19), ${ }^{23}$

\footnotetext{
${ }^{23}$ This text was entitled 'Our Empire Day Pageant' and was intended to be performed in a school playground to mark the official birthday of King George V. Written in an imperialistic and didactic tone, the first part of the pageant depicts Britannia as "Mother of Nations" (4) calling on her "dear children" (8) - her colonies and dominions - to join her in the fight to protect France and Belgium against the "German bully" (3). The onesided dialogue is interspersed with stirring patriotic songs and verse. Part 2, entitled "Saluting the Flag", further invokes patriotic feelings in a militaristic school flag-raising ceremony (MS-papers-4698-105).
} 
making changes to present a more balanced view of the war overseas. Thus Gee's pageant is set in 1915, its title becomes (the ambiguous) "Britannia Awakes" and Germany and its allies (Huns, Turks and Prussians) are added to the cast to correct the political imbalance of the source pageant's cast. Gurkhas and Māori boost the British forces. New Zealand secures a bigger part (not played by schoolboy Wipaki but "someone white" (27), as specified by racist Mrs Bolton), and the jingoistic slogan, "We are the Britain of the South" (116). Tellingly, the Kaiser gets the best lines - and delivers them with a comic energy and gusto that belies the real Kaiser's reputation as a tyrant: "Might is right. Power is my reward. I shall trample through the green fields of France. I tear this poppy Belgium from her stem. My heel shall grind her petals in the mud" (58). He is certainly not the "imperious Kaiser" (115) that Gallant Little Belgium refers to later (115). In fact it is the 'Mother of Empire', Britannia, who is imperious: “Oh, fight we must and fight we will. Who will follow? Sons and daughters, speak!" (116). This parody is followed by a symbolic enactment of the anticipated defeat of Germany: the "British bulldog" kills the "German bully" (116). Yet the pageant, what Hedges calls "jingoistic huff and puff" (111), has a serious message for the novel's child characters and its young readers: might is not always right, and neither is war.

In its local context, the pageant also has resonance. After drawing parallels between Jessop's familial wars and the pageant's war in her thesis, Vivien van Rij concludes that Jessop is "a microcosm of warring Britain and Europe" (52). I would like to use a similar analogy for what I earlier called Jessop's local war, where imperialism and nationalism battle. To illustrate this in tableau form: on one side of the stage we could imagine Britannia stands as the controlling Mother of Empire with Mrs Marwick, Chalmers, and mother-substitute Mrs Bolton, who all dominate their children and war against their independence. On the other side we could envision the "sons and daughters" of the Empire 
in their colourful garb - New Zealand, India, South Africa and so on - who will seek their independence from the Motherland. Off-stage right are "tradesman" (47) Hedges and baker Wix, men who know "they lived in a rough little island at the end of the world, where Christmas came in summer and no man had a master" (46). And off-stage left is Lotte Stauffel, whose marriage to Hedges will bring cultural integration and a New Zealand identity. My tableau, then, portends what is to come.

\section{Mob violence}

It is the mob violence that erupts in Jessop after the pageant that bears the closest resemblance to the violence of war. The mob's behaviour as it approaches Lotte's house is likened to a pack of wolves:

A black wave of figures advanced into the street, filling it to the sides, with eyes and hands and teeth, white like foam....

With their yellow eyes, panting mouths, they were like wolves in an Arctic night....

They knocked Hedges down and trampled on him. They burst through the front door, jamming in it, tearing at each other to go first. A baying and yelping came from them. (The Fire-Raiser 120)

This kind of primitive behaviour is called a 'collective infection' (von Franz 173).

Marie-Louise von Franz, an associate of Jung's, explains the term in this way:

[...] the shadow is exposed to collective infections to a much greater extent than is the conscious personality. When a man is alone, for instance, he feels relatively all right; but as soon as "the others" do dark, primitive things, he begins to fear that if he doesn't join in, he will be considered a fool. Thus he gives way to impulses that do not really belong to him at all. (von Franz 175) 
Certainly 'collective infection' would explain the actions of Ray Stack's father at Lotte's house: "[He] came running through the house with an axe from the garden shed. $\mathrm{He}$ attacked the piano with it, chopping like an axeman at a fair" (121). Christina Jarvis offers another psychological term, the process of 'deindividualization', to explain how individuals involved in group violence (like Stack) often feel less accountable for their actions and are ready to commit further violence because it is for a greater cause such as religion or political beliefs. She goes on to say that the military use this process to prepare soldiers for war (Jarvis "Violence"). Here, explicitly, is a direct link between the Jessop mob and war.

Countering the violence of the mob are Lotte and her music. Her home has been vandalised, her signifiers of culture destroyed. All that is left of her piano (and her livelihood) are "charred remains" (122). However, the mob did not burn her fingers and so she will still be able to play the music that Gee suggests is the antidote to destructiveness and war.

Thus what happens in Jessop over the two week timeframe of the story parallels the war overseas and, indeed, may be viewed as an allegory of war. The town's citizens mimic war and its effects in their everyday lives. By exposing young readers to the local war in Jessop, Gee may hope that they will see the harm of war in its wider context. 


\section{The Champion}

While racism was part of Jessop's response to the feelings in the community stirred up by World War I, in The Champion it takes centre stage, precipitated by the arrival in Kettle Creek of a black American soldier on leave who is coming to stay with Rex and his family. Private Jackson Coop has earned the Purple Heart for being wounded in action - at Guadalcanal, where the Americans stopped the advance of the Japanese in the Pacific. But for young Rex, nourished on the gung-ho heroism of RAF pilot Rockfist Rogan in the boys' weekly, The Champion, Jack is not the hero he expected. Set over two weeks in February 1943 during a peaceful time in New Zealand after Japan's defeat in the Pacific, the novel explores the issue of racism in Kettle Creek through its 12-year-old protagonist/narrator who is the older Rex looking back and speaking in his "Standard 6 voice" (7). In fact, Kettle Creek can be seen as a microcosm of New Zealand society at this time and racism its dark shadow.

\section{Sources and influences}

Kettle Creek is based on Gee's boyhood memories of Henderson during World War II: “creek and kitchen and mangrove swamp, poetry-writing mum, a little town with barber shop and billiard room, Yanks in Jeeps handing out packets of gum" ("Creeks and Kitchens" 22). Gee remembers Henderson as "a country town [...] surrounded by orchards and vineyards. Corbans winery stood beside the hill road leading north. Dalmatians were everywhere. People said they were stealing our land while our men were at war" ("Beginnings" 287). Gee also recalls American servicemen visiting the town: "A constant stream of jeeps came in - American GIs and their girlfriends" (qtd. in McLeod 29). Accordingly, Gee paints Kettle Creek with a similar brush, adding the Māori missing in his 
recollections of that time (Constable Davies and Dawn Stewart) to support the novel's theme of racism.

There are many parallels between the young Gee and Rex Pascoe. Much of what is written about the young Gee in chapter 1 of this thesis holds for Rex as well. Significantly, both were orderly 12 year olds. Both were fierce patriots who enjoyed playing violent wargames and fighting with BB guns. And both were devoted to The Champion boys' weekly. At times, says Gee, “I didn’t know if I was writing about Rex Pascoe or Maurice Gee” (qtd. in McLeod 29). Given the acknowledged blurring of the outline between character and the author's younger self, it could be that the novel's adult narrator is Gee himself and that what he has written is largely autobiography. This poses the interesting thought that anti-racist Gee is writing the novel, in part at least, to expiate his own boyhood racism.

About writing The Champion, Gee has said: "I could use personal knowledge this time rather than research" (qtd. in McLeod 29). Nevertheless, he found writing the novel harder work than The Fire-Raiser because he had to constantly check that his knowledge of that time was consistent with what things were really like then (qtd. in McLeod 29). Sources he would have found useful to check such details include Keith Sinclair's revised edition of A History of New Zealand (1980), Nancy Taylor's The Home Front Volume 1: The Official History of New Zealand in the Second World War (1986), W.H. Oliver's The Oxford History of New Zealand (1981) and Sinclair's A Destiny Apart: New Zealand's Search for National Identity (1986).

Gee's depiction of racism in Kettle Creek during 1943 appears to be influenced by contemporary history when assimilation was Government policy, and thus presents a palpable contrast to the liberal and bicultural late 1980s when The Champion was written. 
Despite the much trumpeted Pākehā claim that "New Zealand had the best race relations in the world" (King 471), low-key Pākehā discrimination against Māori was widespread during the 1940s. In 1943, the racist attitudes of some US Marines on furlough in New Zealand led to inter-racial conflict (Day and Plant 63). James Belich makes the following observation about American and Pākehā attitudes towards Māori at this time:

Americans, particularly from the Southern states, sometimes loudly objected to mixing with Maori in pubs and places of entertainment. Pakeha also discriminated against Maori, and sometimes denigrated them, but they did so less intensely and less overtly. [...] it was not that Pakeha rejected racialism, but that they partially excluded Maori from it. Such things as American use of the word 'nigger', and reluctance to take their rest and recreation on the same premises as Maori is [sic] said to have been one cause of violence between American and New Zealand servicemen. (Belich 290)

But racism did not stop at Māori. Michael King states that non-British people were also targeted. As King puts it, most Pākehā still proudly considered themselves British and with this came "a fear and dislike of nations and cultures that were not British" (King 367). During World War II, then, many non-British people including Dalmatians were subjected to social discrimination.

\section{Racism in Kettle Creek}

Kettle Creek is a racially divided community. This section critiques the different types of racism - local and imported - that divide the community. Local racism, that is, discrimination and prejudice by the dominant British-Pākehā group towards the minority Māori and Dalmatian groups, runs as an insidious undercurrent of everyday life in the town whereas the imported racism that enters Kettle Creek with the American GIs manifests itself more overtly. Given that The Champion was written at the tail end of a decade in New Zealand that was marked by biculturalism, Gee's focus here on American race relations and 
racism may seem unusual. Hence, perhaps, Anna Jackson's claim that "The Champion represents a radical shift in terms of its representation of race and racism" (47). Gee's intention in this novel, however, seems not to reflect 1980s biculturalism or to expose deficiencies in New Zealand's race relations (although there is some of the latter, as we shall soon see) but to tell a story about a black American soldier and his relationship with a Pākehā boy during World War II. Nevertheless, it is important to acknowledge the pervasiveness of racism in the town and it is to that discussion I now turn.

\section{$\underline{\text { Indigenous racism }}$}

Mrs Stewart and her half-Māori granddaughter live on a run-down dairy farm on the outskirts of Kettle Creek and supply milk to half of the town. Dawn is the result of an ill-fated relationship between her mother, Rose, and Jimmy, a Māori fencing hand:

They fell in love [...] Rose and Jimmy. And oh, it was wonderful to see - real love. You've never seen so much cuddling and kissing. It was all so innocent and natural. How could anyone have disapproved? But the way Joan Stewart carried on you would have thought poor Jimmy came from Mars and had two heads and purple scales instead of skin. (The Champion 59)

Mrs Stewart's prejudice towards Jimmy seems to be based on colour alone, as the words "purple scales instead of skin" in the quote above suggest. It is a prejudice she transfers to Jack, stopping in her tracks when she sees him with the children. To Rex, "[i]t was as though she'd got one of those pains that stand you still for fear of making them worse" (70).

Disowning her daughter for fraternising with a Māori, embittered Mrs Stewart has been left to raise Dawn by herself. This she does efficiently but without love. Dawn's brown skin is a constant reminder of the now dead Jimmy and Rose's betrayal. Brought up 
as a Pākehā in "clean sandals and skirt" (12) but judged by the colour of her skin, Dawn's sense of racial identity is conflicted. It is not until Jack calls her skin colour "real pretty" (70) and compares it to that of black singer, Lena Horne, that Dawn starts to accept her Māoriness. Furthermore, of the three races on the Rose when it capsizes - Negro, ${ }^{24}$ Pākehā and Māori - it is Māori that survives, a nod perhaps to the 'Māori Renaissance' in the decade before the novel was written.

Kathryn Walls argues that "one thing The Champion does not champion is biculturalism" ("Māori and Pākehā” 34). This argument, of course, hinges on Gee's intentions in the novel (which Walls outlines), but I would point out what I consider two intimations of biculturalism in the text. The first refers to Gee's placement on the Rose of representatives from the three races in the novel, surely not accidental, and Māori (represented by Dawn) as the only survivor of the capsize. As I have suggested in the paragraph above, this could reflect the resurgence of Māori during the 'bicultural' decade in which Gee wrote the novel. The second (and possibly more convincing) example comes later in this section (under the heading 'Imported racism') and refers to the likelihood that the character of Constable Davies in the novel could be "a corrective to the racism of that time".

\section{$\underline{\text { Racism against non-British people }}$}

Less covert is the town's discrimination of the Yukiches. After more than twenty years of running Kettle Creek Wines, the Yukiches are still seen as foreigners. They originate from

\footnotetext{
${ }^{24}$ In the TV series, Jack drowns. His fate in the book (like Mihi in Lyndahl Chapple's long poem Mihi and the Last of the Moas) is less certain, which may be a concession to young readers or a dramatic device.
} 
Croatia but are called 'Dallies' or squareheads', ${ }^{25}$ names they find offensive. Moreover, their wine-making efforts are regarded with suspicion by New Zealanders used to sweet port and sherry:

The vineyard had been a farm once and gone to scrub. Stipan Yukich, coming down from the north in the twenties, had bought it cheap and cleared it and planted vines. Everyone had laughed at him, the Dally who thought New Zealanders would drink wine, and in a way they were right, Stipan had to make port and sherry, extra sweet, to make a living. Now, with sugar short, he was having hard times. Only the Americans kept him from going broke. (The Champion 31)

Stipan's broken English may have hindered his integration into Kettle Creek society but his formidable strength enables him to win over the crowd at the gala and his refusal to buy the black market sugar off Alf points to an even greater moral strength. Integration, however, is no problem for second-generation Matty. He is Gloria's boyfriend, with one foot in the Pākehā world -“a good looking boy of seventeen, a good rugby player and tennis player" (32) - and the other in his Croatian world where he maintains the language and customs of his native land. ${ }^{26}$ As the story ends, the older Rex tells us that Matty and Leo still live in Kettle Creek: "They make good wine and win lots of medals" (173) - approval, perhaps, of the foreigners who have finally become New Zealanders.

\section{$\underline{\text { Miss Betts and racism }}$}

Racism has also infiltrated the school in fierce Miss Betts, the children's teacher. Jingoistic and ethnocentric, she speaks for the British-Pākehā majority in the community -“our boys"

\footnotetext{
25 "Squarehead" is an offensive term that applies to "a foreigner of German extraction, esp. a German (spec. Army slang in the war of 1914-18) or Scandinavian" (OED Online). More generally, it can mean a stupid or inept person. Its application to Dalmatians may be because their often limited grasp of English gave the impression that they were slow-witted.

${ }^{26}$ In the TV series, Gloria's boyfriend was a Māori. Perhaps Gee made the change in the book to highlight the existence of racism against Dalmatians, something he would have been familiar with given their presence in Henderson as he was growing up.
} 
(23) are New Zealand boys, British boys, not 'Dallies' or 'squareheads'. While Anglophile Mrs Bolton upholds "the true English sound" (The Fire-Raiser 59) as the model for how New Zealand children should speak, Anglophile Miss Betts demands correct written English in her class, rejecting New Zealand slang like 'loony', 'gosh' and 'rotten' (47). Her proBritish sentiments extend to discrimination of students from non-British backgrounds like Leo and Dawn. As Rex recalls, "Miss Betts had a game of tapping on [Dawn's] desk as she went by, then tapping Dawn's skull and listening as though the sounds were identical" (24). She plays a similarly cruel game with Leo to demonstrate that he does not have the brains to do arithmetic. Leo, secure in his Croatian identity and dislike of the teacher, withstands her racial insults while Dawn, less secure about her mixed racial identity, becomes solitary and keeps to herself at school.

Miss Betts believes in the racial superiority of the British and explains racial inequality in this way: “[...] some races, Negroes, yellow people, Russian peasants, were not exactly inferior [...] but not so advanced in developing. [...] One day they would well, might - be equal to the civilised races of the world. But not yet, by a long way, poor things, and we must help them and be charitable" (54). How ironic, then, that it is "not so advanced" Jack who confronts the paternalistic Miss Betts with her own stereotypes of Negro behaviour by dancing around her like Al Jolson, an American song and dance artist of the 1930s and '40s: "She could not catch up and bring him in control. No one had ever got the better of Miss Betts, but Jack had her beaten. The fury and bewilderment of her! She could not find a way to stop him" (54). 


\section{$\underline{\text { Imported racism }}$}

Marv Varcoe and Herb Cutter are American GIs from the American South on leave in Kettle Creek. They are the problematic face of imported racism in the town. Overtly racist and aggressive, Marv calls Jack "nigra" $(85,99)$ and "boy" $(85,92,100)$, and constantly demeans him. This episode in Alf's barbershop is just one example of that denigration:

[...] Herb broke up the balls, and Marv [...] lined up his shot. He leaned across the table, potting for a red in the corner pocket, but he miscued - oh it was deliberate - and the cue ball jumped the cushion and rolled across the floor to Jack's feet.

'Well, shoot!' Marv said. 'I guess I need some more chalk.' Then casually to Jack, 'Pick that up, boy.'

I thought he meant me. I was the only boy there. I bent to pick the ball up.

'Not you. The nigra.' (The Champion 85)

The GIs try similar racist tactics on the town's Māori policeman, Bob Davies, but he is more than a match for them: "While you're in town you boys watch your mouths" (30). The reversal of power, from white supremacy to brown authority (vested primarily in Davies' establishment position as a policeman), confuses the GIs. 'Nigras' do not give orders to whites and neither do they break up fights between 'nigras' and whites, as the quietly forceful Davies does at the gala. Davies is an interesting character, not so much for what he does but for what he seems to stand for. He could be seen as a poster-boy for 1940s Māori assimilation into the dominant culture or, more probable given Gee's anti-racist views, a corrective to the racism of that time.

\section{$\underline{\text { Rex and racism }}$}

If Constable Davies is a subversive character, how might we see Rex Pascoe? At the start of the novel Rex is a racist, which sets him apart from his non-judgmental family. He wants 
nothing to do with Jackson Coop, rejecting him solely on the basis of his racial identity: "I saw his face. He was a Negro" (36). But Rex's prejudices go deeper than that:

[...] Most of us in Kettle Creek had only seen Negroes in the pictures porters on trains, bellboys and cooks (fat ladies who were always laughing), or trumpet players in the dance band. Jackson Coop was rare - unique - like, say, one of those African animals brought to ancient Rome, an ostrich or hyena or giraffe. I don't mean we wanted to put him in an arena and make him fight, though later on it came close to that. But some of us would have liked to have put him on show and walk around and prod and poke him. (The Champion 39)

Rex's use of the inclusive pronouns 'we' and 'us' in this passage reveals his identification with the views he reports. Similarly, his relegation of blacks to the lower rungs of the evolutionary ladder (as exotic animals or slaves) discloses his innate sense of racial superiority and subsequent hostility towards Jack. This hostility spills over into his dealings with Dawn Stewart whom he dismisses as "only a Maori" (35) and Leo Yukich whom he has called a "squarehead" (25).

Other factors contribute to Rex's racial arrogance. There are the stories he reads in the boys' weekly The Champion, where the Germans and Japanese are depicted as subhuman races to be defeated by imperialistic white heroes like Rockfist Rogan. Then there are the war games he plays with other children, dispatching Germans and Japanese with the words "Take that, Jerry!" and "Die, yellow dog!" (9). Both activities smack of xenophobia. And in the community itself are role models for racism, including his father who calls Jack a "darkie" (39).

It takes some time for the war-like Rex to learn the lesson that Gee has set for him and to see the humanity in Jack. In this respect, Rex's patient teacher is Jack himself, and Jack loves peace not war. As Rex discovers, Jack's 'otherness' is only skin deep: "Jack and 
I went on to the road and round to Grandma's for my bike. We talked of this and that: worms, canoes, dogs, cricket, baseball, as we went. I began to see he wasn't the person I had thought he was. I had to go right back to the beginning and meet him again and go from there" (72).

Rex also learns about himself in the process of getting to know Jack properly and becomes more humane. He can recognise his own cowardice, which he has projected onto Jack, and admit that he too would run away from mobs like the one that killed Jack's father:

I dreamed that night of mobs and Marvs and rats as big as dogs, and Jack standing up to them and other times running away.

I stood by his side.

I ran away too. (The Champion 87)

Furthermore, Rex can empathise with Jack's experiences of racism - the Chicago slum, his daddy's murder and his victimisation by Marv and Herb - and begin to treat Leo and Dawn fairly and respectfully, as Jack does. He cannot yet treat Jack as an equal, although he starts to feel possessive about him and boasts about his Purple Heart at school. This feeling changes to hero worship following Jack's performances at the gala and in the boxing ring. Projecting himself once again onto Jack, Rex claims his victory: "I had my Jack. I had my Buddy Storm, my Rockfist Rogan” (100).

Before long, Rex replaces this idealisation of Jack with a proper view of him. Jack becomes his friend but Rex "knew he wasn't perfect. [He] knew he was scared of things, scared of Japs. In the water, dog-paddling (trying to), he was worse than a primer kid" (120). This acceptance of Jack's difference (and that of Leo and Dawn's as well) shows Rex's growing maturity and is based on seeing Jack as an individual and not through his racial identity. In this way, "Private Monkeyface" (40) becomes Rex's champion. 
By the end of the novel, Rex has learnt Gee's big lesson: that judging people by their skin colour and race is wrong. Egalitarianism and open-mindedness, Gee seems to posit, are antidotes to racism and two of the ingredients for a more tolerant society, whether that society is Kettle Creek or New Zealand.

Gee takes a humanist's position on war and racism in these two novels. Neither is right nor justified. Both themes are potentially challenging for young readers but Gee uses literary techniques such as distancing, allegory and symbolism to provide an emotional buffer between those themes and his readers. Related to the themes of war and racism in these novels are other issues important to New Zealand and New Zealanders: imperialism, nationalism, and national identity. These are themes, or versions of themes, that occupy Gee and his characters throughout this sequence of five historical novels. 


\section{Chapter 3}

\section{"Expanding Scenes of Violence" in The Fat Man}

Gee's preoccupation with violence is fully realised in The Fat Man, which was published in 1994. For this reason, it is the central novel in my study of violence in his historical novels for children. Set in a small prohibition town in New Zealand during the Depression, the novel tells the story of Herbert Muskie, the eponymous fat man, who returns to his hometown after a long absence and threatens the safety of Colin Potter and his family. Better known as a contested text for junior readers (as described in the introduction to this thesis), the novel can also be read as a convincing portrayal of psychosociological violence - its perpetrators and victims, its manifestations, its motivations and its effects - that intends to reveal as much about family and society in New Zealand from its 1930s setting to contemporary times as it does about the violent man and the frightened boy at its centre. The word 'portrayal' is important here because there is a difference between violence in society and its representation in literature. Violence in society is real. In fact Jane and James Ritchie argue it is part of the cultural pattern of who we are (Violence in New Zealand 17). The literary representation of violence, however, is a fictional representation, an imagined and creative construction of violence shaped by a writer to meet the demands of story and character.

In what follows, I investigate different representations of violence in The Fat Man under three main forms: individual violence, family violence and social violence. My analysis is based on a psychosociological reading of the novel and organised within a similar frame to Otto Heim's “expanding scenes of violence" (25) under which, as outlined in the introduction to this thesis, he presents his thematic discussion of contemporary Māori fiction. Whereas Heim maps the ripple effect of violence from within the family to broader 
systemic forms such as war and terrorism in the novels he discusses, Gee tracks the smaller trajectory of violence in his novel from the violent man to the family setting to the wider context of Loomis society. Gee's purpose, I argue, is to show violence as an expanding and damaging force across these three different spheres of his novel.

\section{Sources and influences}

As he has done in The Champion, Gee mines his own family history in The Fat Man as a starting place for setting, character and story. Loomis is based on Henderson, the small country town Gee and his brothers grew up in. Laurie and Maisie Potter are drawn from Gee's parents and their experiences during the Depression, while the method of parental discipline used by Len/Laurie Gee (a willow stick) is duplicated by his namesake in the novel. ${ }^{27}$ Chapter 1 of this thesis describes how Gee's father would give his sons hidings for misbehaving and it is almost certain he received the same treatment from his own father who, according to Gee, "was always on about kids needing hidings" (qtd. in Holloway 23). This autobiographical detail has been confirmed by Gee in interviews with Judith Holloway and Agnes Nieuzenhuizen (and others) and in his own accounts of his childhood such as "Beginnings" and "Creeks and Kitchens".

Young Maurice would have been two in 1933, the year in which The Fat Man is set, not old enough to remember the Depression. But through his parents' stories it became part of his history:

I came to know the Depression as Enemy, and Len and Lyndahl Gee as heroic beings. The life of my imagination stretched back beyond my birth [...] I saw Dad pedalling his bike after the loaded timber truck. His carpenter's kit was slung over the handle-bars. If he kept the truck in sight he might get a day's work stacking

${ }^{27}$ Gee referred to his father as "Laurie" in a conversation with Judith Holloway (qtd. in Holloway 23). 
timber. I saw Dad's father, who had been a builder, painting white lines on the roads, and Mum on her feet at a Labour Party meeting telling everyone straight what had to be done. ("Beginnings" 289-290)

Beyond autobiography, Gee would have found other sources useful when writing the novel. His earlier novels for adults, Games of Choice (1976), Plumb (1978) and Meg (1981), had covered the Depression years. Tony Simpson's The Sugarbag Years, first published in 1974, was a popular and widely read collection of people's accounts of the Depression. Gee is sure to have consulted this, as well as Jock Phillips' A Man's Country? (1987) for its social history of 1930s masculinism, and the second edition of the Geoffrey Rice-edited The Oxford History of New Zealand (1992). Similarly, Mulgan's Man Alone and Hyde's Nor the Years Condemn, first noted as sources in chapter 2, would have been compulsory reading for their contemporary depictions of 1930s New Zealand.

\section{Individual violence}

This section explores representations of individual violence - aggressive or forceful acts performed by individuals at the microlevel of society - through the character of the fat man, Herbert Muskie. As Gee's historical novels for children shows, individual violence is a masculine trait the author views through the lens of the violent man. The violent man is also a familiar trope in Gee's fiction for adults and, indeed, in some of the classics of New Zealand fiction such as John Mulgan's Man Alone, R.H. Morrieson's The Scarecrow and Keri Hulme's the bone people. ${ }^{28}$ In this fiction, the trope reflects not only social reality but also an enduring credential of masculinity in New Zealand literature. Jane and James Ritchie, for instance, point to the male pattern of violence in New Zealand (Violence in New

\footnotetext{
${ }^{28}$ There is, of course, a violent woman in the bone people but Joe Gillayley's physical abuse of his ward, Simon, in my view, defines the violence in the novel.
} 
Zealand viii) and Kai Jensen observes that Gee's character Rex Petley "possesses the masculine credential of violence" (Jensen 165).

We met earlier versions of Gee's violent man in chapter 2 of this thesis, namely Edgar Marwick and young Rex Pascoe, and in chapter 4 he reappears, in a less dominant form, as 'Bike' Pike in Orchard Street and Errol Richardson in Hostel Girl. But Herbert Muskie's violence in The Fat Man overshadows that of these violent men, putting him in the same league as a similarly disposed character in a novel for adults and thus challenging the boundaries of what is acceptable in a novel for children. Hubert Salter in Morrieson's The Scarecrow, for instance, rapes, murders and commits necrophilia. Muskie abuses his wife and step-daughter, murders his mother and abducts the children. There is, however, a difference in the treatment of the violent man by both authors. Morrieson unflinchingly depicts Salter as a depraved man with no redeeming qualities, the motivation for his violence sexual gratification and his committal to the putrefaction of the local tip a fitting end. Gee allows his young readers to see the humanity in Muskie by offering some explanation for his violence and the possibility of redemption through death.

Herbert Muskie is a complex character, a 'mixie', in whom the Manichaean balance between good and evil has tipped towards the dark side. This imbalance is reflected in his excesses, the most obvious being his appetite for food and violence. More revealing, perhaps, in terms of the characterisation of the violent man, is Muskie's inability to control either of these urges. Other dualities indicate Muskie's divided state. Muskie has a puritanical obsession with cleanliness and good manners but is associated with corruption and impropriety. He loves his mother but he drowns her. He prides himself on controlling his emotions but quickly becomes unpredictable and dangerous. His dominance reverts to child-like subjection at the end of the story. These ambiguities resist the simplistic reading 
of character suggested by the novel's title and demonstrate the flawed humanity of the fat man.

Flawed humanity, in fact, is what C.K. Stead attributes to Gee's antagonists in general, when he describes them as "equally real and equally repellent" (Stead 326). This description could also apply to Herbert Muskie whose physical imperfections - his fatness, his balding hair, his scar "like a maggot" (78) in his cheek - are repeatedly emphasised in the novel and invested with meaning beyond the physical. His other 'faults' - acts of violence including crime, abuse, bullying, intimidation and murder - mark him as so morally corrupt that some readers may find their stomachs turning, as Colin did (63). ${ }^{29}$

Gee makes some concessions for his young readers. Sexual violence is suggested in the novel, implied in Muskie's treatment of Bette and his intentions for Verna. About this, Gee has said, "If I'd been writing the story for adults, that's something I'd have had to look at ... But I didn't move into those areas because I wanted to keep [the story] on the level of a child's understanding" (qtd. in Holloway 22). This he has achieved by telling the story through Colin's eyes, and innocent Colin, like Gee's young readers, is not aware of those sexual undercurrents. As alluded to earlier in this section, Gee balances his characterisation of Muskie by showing the origins of his violence in the unhappy childhood and the relentless bullying at school. (Both these aspects will be discussed in more detail later in this chapter.) And, in another nod to his readers, Gee the humanist offers an alternative to Muskie's violence in the pacifist, responsible Colin.

Psychological violence like intimidation and fear mongering plays a big part in Muskie's ability to control his victims. For most of the story, Colin is terrified of the fat

\footnotetext{
${ }^{29}$ So did Dorothy Butler, according to her letter to the New Zealand Listener on May 131995 (12).
} 
man. Waking in the night, Colin remembers “... a razor perhaps, or a scar like a worm that wriggles in a cheek, or the terrible quickness he can move with - a fat man moving with a dancer's speed. And the strength in his white hands. The darkness in his eye" (40). Muskie's ominous violence is here implied in the word 'razor' as well as in his preternatural quickness and strength. It is intimated in the way he has lodged himself in Colin's mind. It is embodied in his threatening physical appearance - his gross bulk, worm-like scar and dark, menacing eyes. Colin has earlier described those eyes as "blacker than sheep pellets" (14), an intensity of darkness that both threatens and repels. If, as the saying goes, eyes are the window to the soul, their comparison here to sheep pellets (in Freudian terms, fecal matter) reveals Muskie's inner contamination. Physical difference and violence are thus disturbingly linked in Muskie who becomes a subversive version of the traditional masculinity represented by the energetic and muscular Laurie.

As suggested earlier in this section, fatness has more weight than mere physical representation in The Fat Man. This is not to say that fatness is seen as implicitly violent, rather that it becomes associated with violence as an indicator of Muskie's appetite for selfgratification. Muskie is engorged by his illegally gained wealth and the powerful psychological (and sexual?) satisfaction he gets from setting up his revenge. Manipulation and influence are his tools of the power trade. He exploits his victims' weaknesses, not just Colin's greed for chocolate but also Laurie's pride in his boxing cups and Grandpa's gullible nature: "It was as if he knew every secret, as if he had some power over them" (90). Moreover, Muskie cunningly wins the favour of the townsfolk, and the Potters in particular. He dupes Loomis into thinking he is the prodigal son made good and come home to care for his old mother. He buys Laurie and Grandpa's loyalty with regular work and good wages, sweetens up suspicious Grandma with the steady income he provides the 
boarding house and tempts the uneasy Maisie with gifts of oranges. ${ }^{30}$ Colin can see what the fat man is doing but is too scared to say anything.

Muskie increases as he reduces his victims. Colin becomes a snivelling baby, his face smeared with the chocolate he steals from Muskie, while Muskie appears to be larger than life: "He took his jacket from the ferns and shook it out and put it on. It made him look even bigger" (19). Laurie, after losing to Muskie at arm wrestling, "seemed to shrink as if some of his weight was lost" (96). Muskie swells with triumph: "It's a long time from Loomis school, eh Laurie?" (96). But it is Muskie who is absorbed at the end of the story and Colin who grows, in the exchange of power that occurs.

According to Brenda Stone, Muskie is not the only 'character' in the story that manipulates and influences. She claims that by foreshadowing significant events the novel's intrusive narrator similarly manipulates and influences readers (93). Thus "in watching the characters playing out the fat man's plan we become his silent accomplices unable to warn or intervene" (Stone 93). In this way, Stone argues, "the novel performs its themes not only within the story but also in the mind of the reader" (93). This feature may explain criticism of the novel as a text for young readers, she suggests. Colin is likewise a silent accomplice, tied to Muskie by an "invisible rope" (26) and unable to tell his fallible parents about the fat man. Only when he sees the humanity in the fat man and can call him Herbert Muskie is he "able to talk and act and do things at last" (121).

It is perhaps in its more primitive representations that the real nature of Muskie's violence, and the author's attitude to violence, is revealed. We have seen Colin's terrified reaction to the man who was "like something that had rushed into the daylight from the back

\footnotetext{
${ }^{30}$ Louise Clark argues differently, saying Herbert Muskie "[u]ses food as a means of control - the chocolate bar which Colin takes from Muskie's rucksack, the oranges Muskie brings to Maisie and the beer he smuggles illicitly into Loomis" (Clark, "Writing Vertically and Horizontally" 82).
} 
of a cave (my italics) and was looking at what it had caught. For a moment, Colin believed he was going to be killed" (14). There is surely some archaic and violent force being attributed to Muskie here, who appears as a primordial predator so frightening he defies naming. This impression of an ancient force at work seems to be confirmed in Mark Williams' observation (in relation to Gee's work in general) that “[...] in Gee, the violence springs from a level of the human mind that precedes the construction of social order" (174) and reinforced in The Fire-Raiser when Clippy Hedges accuses Noel and Phil of using the prehuman part of their brain, the unthinking "reptile brain", to fight like thugs (32). In Muskie, there is evidence of this reptilian behaviour in his repeated association with darkness and filth, and in the nature of his violence. Gee makes this link between the "reptile brain" and violence explicit in his fantasy novel, Motherstone. Freeman Wells, through the medium of the stone, talks of the 'swamp beast' (a Jungian reference to prehuman behaviour) still being in Humankind: "The swamp beast overcomes us and when we should think we bellow, we strike and tear - and fall back into that dark place where self is all" (Motherstone 122).

The words we most associate with Muskie are 'cave', 'creek' and variations of 'underground'. In this novel, they have a literal and a psychological meaning. Taken literally, these words are the names of geographical features found above or below the ground. In a psychological reading, they represent the primeval and elemental in Muskie's psyche. Hence Muskie rushes like a predatory beast from "the back of a cave" (14) and in a later passage is described as coming through "from the dark place" where he lived (115). Similar imagery is used to describe Colin's fear that Muskie had somehow emerged literally from the bowels of the deep: "The fat man had come up out of the ground, as though he had been sleeping there, buried for years, waiting for something to wake him - or come up from the deep pools of the creek, dripping slime" (26). (My italics) While I do not want to 
impose a purely psychological reading on the violent man, some discussion of the implications of such imagery is necessary now, to illustrate the dark forces of the human psyche that Muskie seems to represent.

In Jungian terminology, Muskie may be seen as 'the shadow'. The shadow, says George Boeree in an article about the personality theories of Carl Jung, is an archetype originating from our prehuman, animal existence "when our concerns were limited to survival and reproduction, and we weren't self-conscious". It represents the "dark side" of the ego and is often the repository of our capacity for evil ("Personality Theories"). In Muskie's case, this darkness manifests itself as a primitive violence. Further, states Boeree, the shadow "often guards the entrance to a cave or a pool of water, which is the collective unconscious ("Personality Theories"). It may be the latter that Muskie is symbolically protecting as he rushes out of the cave towards Colin and later emerges, in Colin's imagination, monster-like from the depths of the creek world. Jungian theory may also be applied to Colin who stands for another archetype, the 'hero'. As Boeree explains, the 'hero' represents the ego and is often depicted as a story character whose task is to fight the shadow, in whatever form it manifests itself ("Personality Theories").

Allusions to excrement and urination in the text seem to reinforce Muskie's connection with filth. He is described as emerging from the creek "dripping slime" (26), he loves chocolate and, as mentioned earlier, his eyes are "blacker than sheep's pellets" (14). In Freudian symbolism, slime and chocolate have connotations of faeces while sheep's pellets denote faeces. Also, Muskie's surname may be derived from its homonym 'musky' with its general connotations of smelliness and the scent-marking of odorous substances, including urine, by animals while the name Loomis children call his mother (and called him 
as a child and later his step-daughter) - Mustpee - again refers to urination and, perhaps, incontinence.

Similarly primitive is Muskie's forcing of Colin to eat the chocolate bar he has "dropped a gob of spit on" (15). ${ }^{31}$ This violent act, the forced ingestion of body fluid, is analogous to that experienced by the young Muskie whose school mates made him eat spit sandwiches every day, and symbolises Muskie's possession of the boy - just as Pottsie and his friends possessed young Herbie a generation ago by making him eat spit sandwiches. In her PhD thesis, Vivien van Rij develops the symbolism of this act in relation to both incidents. She argues that by forcing Colin to eat his spit, Muskie is expressing hatred similar to rape. Colin is "literally the recipient of the fat man's juices, symbolically impregnated with the seed of evil" (van Rij 132). Further, she claims that Muskie's similar childhood experience is like a gang rape by Laurie and his friends, in that they all take turns to spit inside the sandwich before reassembling it. ${ }^{32}$ Van Rij's argument seems overdone. Another way of reading these incidents is simply to see them as childish acts performed by Pottsie's gang and later by Muskie. Spit (and spitting, as we know from Verna's response to her bullies at school) has playground connotations that sperm does not. Read this way, Muskie's act becomes more a juvenile form of retribution (through Colin who stands for Muskie's childhood bullies) than symbolic rape, and so reveals his arrested development.

\section{Family violence}

Drawing on a variety of sources and with the benefit of hindsight, Gee builds up a convincing picture of family life in The Fat Man. In this section, I will discuss how part of

\footnotetext{
${ }^{31}$ Gee also uses this unpleasant form of retribution in Sole Survivor. Sutton, who loves Bluey and whom George Plumb regards as primitive man, drops a gob of spit into the priest's teacup because "he was the one who had stolen Bluey [for the church]" (94-95).

${ }^{32}$ See van Rij, pp.132-133, for more detail on this argument.
} 
that family life - family violence - is represented within the novel's Potter and Muskie families. But first I will outline the sociohistorical context of the novel, based primarily on Jock Phillips' social history, A Man's Country? Phillips' book would have been one of Gee's main source histories when writing The Fat Man and surely influences his depiction of family in the novel. The operative word here is 'influences'. Gee's depiction of family does not mirror the social pattern of the time but it certainly resembles it.

In the 1930s New Zealand was a patriarchal and authoritarian society, secular in nature and largely British by identity (King 366). Although women had gained suffrage in 1893, they still had no real economic or political power. The nuclear family was the cornerstone of society and the roles of its members were socially prescribed. It was an institution that privileged the imbalance of power between male and female, adult and child. Father was the breadwinner and disciplinarian. Mother managed the home, brought up the children and was responsible for the moral tone of the household. Children were expected to obey their parents. (As we saw in chapter 1, this was the model for Gee's own family.) Yet within the private sphere of home, women tended to preside, especially during times of hardship like the Depression when many men were away from home on relief or looking for work. Home was perceived as a place where "masculinity and male power ended at the doorstep" (Ireland 72). It could also be a place where the different worlds of men and women collided. According to Phillips, "the problem was that the male had to straddle both worlds. He was socialised into the exclusive culture of men; but his own inner needs and society's demands for social order encouraged him to become a loyal family man" (259). That conflict between two images of masculinity, what Phillips calls 'the man's man' and 'the family man', ${ }^{33}$ could lead to domestic violence (259-260).

\footnotetext{
${ }^{33}$ A 'man's man' was perceived as strong and tough. Self-sufficient and stoic, he valued mateship above family life (Phillips Chapter 4). A ‘family man' was seen as a loyal provider, a faithful husband and caring father (Phillips Chapter 5).
} 
Similar tensions within the family existed in the mid 1990s when Gee wrote The Fat Man, although the social pattern had changed. Second-wave feminism had brought advances in gender equality but women still had the primary responsibility for childrearing and running the household. While there is no direct evidence of domestic violence increasing at this time, more incidents were being reported and convictions for male assaults on women and children had trebled (Belich 500). Home was no longer necessarily regarded as a moderating influence on men and a sanctuary for family: "By the 1990s, perceptions [of home] were very different. Now there was a suspicion that men brought all their emotions home, and within those sacred walls let it all hang out by abusing the people who were closest and most vulnerable" (Phillips 274).

Some of these tensions - historical and contemporary - appear to inform Gee's portrayal of the families in this novel, and help to convey its social message. Particularly relevant are the tensions around gender roles and masculine identity exemplified by Laurie Potter and Herbert Muskie.

I turn now to a discussion of family violence in The Fat Man. Whereas in the previous section Herbert Muskie's violence was attributed to power-seeking and powerbased relationships, here the violence is established in two ways: as discipline and the imposition of order in the family setting and the abuse of family members by its putative head.

By comparing the Potter and Muskie families, Gee gives us insights into some of the reasons for family violence within the context of the story and, by implication, in contemporary society. The extended Potter family (including Grandma and Grandpa Potter) seem to represent a positive image of a close-knit family, albeit one struggling to make ends 
meet during the Depression. Laurie is perhaps Phillips' 'family man' with its associated provider responsibilities, his former boxing and rugby playing days replaced by play fights with Colin. Work gained by chasing the timber truck on his bike and outside jobs at home (manly tasks such as chopping wood and growing vegetables) help keep his masculine identity intact and minimise potential conflict with Maisie's domestic world.

Yet Laurie has been diminished by the Depression. His three months in the relief camp and the sale of his boxing cups (symbolically, his masculinity) have demoralised him while desperation for steady work effectively means he has been bought by Muskie for "three months of good wages" (75). There is a sense of repressed violence about Laurie that suggests he has not completely accepted the role of family man (and that draws him to Muskie). He still likes to be seen as strong and tough. Sometimes he flicks Colin too hard in play fights and occasionally he is aggressive, as when he threatens Colin: "I've just about had enough from you" (120), and orders Maisie to get his tea so he can go out with Muskie. On these occasions Laurie dominates his family, like a sanitised version of Muskie (and recalls the stereotypical father of Phillips' social history of the 1930s).

Like Lyndahl Gee whom Gee describes as "a kind of moral exemplar" ("Creek and Kitchen" 87), Maisie enforces the moral tone of family with puritanical edicts about behaviour that apply to her son and, to a lesser extent, her husband. There is, for example, to be no bike riding on Sundays (54), colloquialisms like 'ain't' are not proper English (47), food must be chewed thirty-two times before swallowing (9) and displays of affection are rationed and private (43). While Maisie does not approve of overt violence like "men punching each other" (42) or simulated violence like the play gunfights Colin and Laurie enjoy, she appears to have no qualms about the 'motherly' violence she imposes on her "quiet, gentle boy" (127). She bullies him and threatens him with physical punishment from 
Laurie: "My word, young man, you'll be in hot water. I'll send your father after you. And just look at your clothes, coal on your trousers" (57). She punishes him for speaking out of turn - "we don't want you when you're like this" (120) - and berates him for interrupting his father. Although both parents dominate Colin and expect him to do as he is told, as was the case in the authoritarian 1930s that Gee recalls (qtd. in Holloway 23), Maisie's domination over Colin is absolute. She orders him to do as he is told when he tries to get out of taking Verna to school: "Colin! I'm not telling you again. Now go and clean your teeth. And make sure your fingernails are clean" (72).

Colin is a peaceable boy who does not like fighting or dissension between his parents. He enjoys working outside with his father: "It was a race but it didn't matter who won, not like in boxing, where you had to knock someone out" (43). He would rather his parents kissed and made up than "not speak a word to each other for the whole Sunday" (46) when Laurie found out Maisie had sold his boxing cups. Apart from the threats of violence from his parents, Colin gets the odd hiding from his father. He knows that a willow stick hurts. That form of discipline was socially acceptable in Laurie's boyhood, too. He was whacked "plenty of times" (58) by his father and earned a "proper tanning" (51) from Harry for nearly drowning Herbert Muskie. Thus Gee shows young readers how society's attitudes towards the physical punishment of children by their parents have changed over time and invites them to think about what might have caused this shift in attitude.

Conversely, the dysfunctional Muskies represent a negative image of family. Bette is neither a domesticated nor a moral force. Those traditional female roles are taken by Muskie who, like Maisie and Grandma Potter, is obsessed with cleanliness, tidiness and propriety. Add to this Muskie's unmanly shape and we see a feminine side (the anima) at odds with the hyper-masculinity of his gangster persona. In Jungian terms, the persona 
represents our public image. We can choose to present the favourable side of ourselves to others or, as Muskie does with his hyper-masculine mask, present a false impression to manipulate what people think and do (Boeree "Personality Theories").

Given the falseness of his persona, Muskie seems to be an ironic embodiment of the conflict between Phillips' images of masculinity discussed earlier in this section - the man's man and the family man. ${ }^{34}$ But where in Laurie this conflict manifests itself as occasional threats and aggression towards Maisie and Colin, in Muskie it erupts as domestic violence. Muskie dominates his new family (much as his father dominated his family): "What the fat man said, Bette and Verna had to do" (72). They are too frightened to escape. He verbally abuses, humiliates and beats Bette. Sexual violence is implied (but not explored by Gee for reasons outlined in the first section of this chapter). The male body has become the site of violence and authority.

Verna, a silent witness to her mother's abuse, also suffers at Muskie's hands, powerless to repel attention from him that is neither welcome nor fatherly. He razors off her curls to "make her ugly" (117) so that no-one will love her. Equating physical imperfection with being unlovable and unloved is a lesson 'Herbie' almost certainly learned from his father's beatings and his siblings' taunts. But what do we make of Muskie's satisfied comment to Bette - after he has forced Colin to say that he does not love Verna now that her curls have gone - that cutting off Verna's hair has "saved her from a fate [that is, love] worse than death?" (118). On the one hand, his comment tellingly debases love while on the other hand, in a grimmer sense, it may imply that what he has saved Verna from is less significant than what he has saved her for. This incident, and Muskie's stated intention to get rid of Bette but keep Verna (114), alerts us to the possibility of incest. It is a possibility

\footnotetext{
${ }^{34}$ There was a fear that in becoming a family man, a man surrendered his masculine identity (Phillips 242).
} 
earlier foreshadowed by the tune "Three Little Words" that Muskie was whistling as he came down the stairs with his razor. Ominously in this context, because what Muskie feels for Verna is an unhealthy sexual attraction not love, those three words are "I love you" (117). Family violence, then, in the Muskie household becomes a means of family dominance.

It is not hard to argue that the root of Muskie's violence lies within his own family which has set the patterns of abuse that he replicates as an adult. A close reading of the text reveals where the author's sympathies lie. As a fat, and possibly unattractive, child, it seems that 'Herbie' was denied the "love and understanding" (58) that Bette rightly identifies all children need. Instead he was victimised for his difference by those who should have protected him, regularly beaten by his father, who "never hit Clyde [...] or the girls" (58), and tormented by his more favoured siblings - "pretty girls" (51), says Grandma Potter about his four sisters. That violence was condoned by the family, including Herbie's mother who loved him but could not save him from it. This harsh treatment has left him emotionally damaged, unable to love or feel empathy. Thus he can abuse his wife and stepdaughter, disinherit his siblings and make his brother destitute by closing the mill.

Muskie's feelings for his senile mother, who has effectively been abandoned by her children, are more ambiguous and lead to her death. ${ }^{35}$ Muskie has almost certainly drowned his mother but is distraught after her death. Verna, in fact, sees him in his mother's bedroom, hugging her pillow and sucking his thumb (112). Ambivalence towards close family members, especially sons towards mothers, is not unusual in Gee's fiction generally. For instance, David Macpherson in Gee's adult novel Loving Ways (1996) rationalises murdering his wife: "He knew how much he loved her. But the more he loved her the more

\footnotetext{
${ }^{35}$ Son-to-mother ambivalence features in, for example, Gee's The Fire-Raiser, In My Father's Den and Crime Story, and may reflect Gee's feelings towards his own mother.
} 
he knew she had to be punished" (148). Colin perceptively identifies similar conflicting emotions in Muskie: "He cried for [his mother], but he killed her too" (122).

We know that 'Herbie' and his mother were very close - he was his mother's favourite child, the last to leave home, and she waits every day for the Auckland train to come in, hoping he will return. There is, nevertheless, the suggestion of a different relationship contained in the words of "Old Fashioned Mother", which Muskie orders Bette to sing in memory of his mother:

How well I remember in years long gone by,

Together we sat, she and I,

More like two old sweethearts than mother and son,

In days long since gone with a sigh .... (The Fat Man 112)

If incest between mother and son has been normalised, this could explain why Muskie sees nothing wrong in continuing the practice in his new family and why he regards females as sexual objects.

\section{Social violence}

In this final section of chapter 3, I will discuss representations of social violence in the wider context of Loomis society where it is either a response to the subjugation of the Depression or embedded in the town's social structures and norms. Social violence is defined here as a 'catch-all' for illegal, socially sanctioned and anti-social acts that include crime, corporal punishment and slander.

New Zealand in the 1930s was assailed by many forces, two of the most significant arguably being the external force of the Depression and the internal force of puritanism. 
Both seem to inform Gee's depiction of social violence in Loomis, and so it is useful to briefly background them. Looking first at the Depression, we can see in historical accounts and fiction of that period its oppressive effects on the population and the social violence it precipitates, ${ }^{36}$ and find in Gee's personification of it as "a hairy beast devouring people" (“Creeks and Kitchens" 14) and "Enemy" ("Beginnings" 289), an indictment of capitalism. That Gee believes the "hairy beast" ("Creeks and Kitchens" 14) exists today but in another guise further points to his socialist leanings. Indeed his wife has described him as a "true socialist" (qtd. in Brett 101).

One historical source that clearly shows the Depression as an oppressive force that led to social violence is Tony Simpson's The Sugarbag Years (1974), which records, in their own words, the experiences of ordinary people who lived through that time. The following extracts from Simpson's book not only attest to the effects of the Depression on individuals, families and communities but they also register people's feelings and perceptions about those years in a way that is uncommon for a history book. I include the extracts here to show the closeness between the reality of the Depression and Gee's realistic portrayal of it in The Fat Man. The extracts are presented in alternating plain and italic text (as in the book) and the page numbers apply to the first edition of the book.

We saw a lot of hardship. There seemed to be despair, unhappiness, a general despondency. People were wondering what they were going to do. (35)

We were very poor. We never had sufficient food or clothes. [...] we didn't have overcoats $[\ldots]$ We had no shoes, but for footwear sandshoes were the thing because they were the cheapest of the lot [...] We had two pairs of pants for years - there were the pants that you wore, and your good pants. (18)

\footnotetext{
${ }^{36}$ See 'Sources and influences' earlier in this chapter for historical accounts of the Depression.For contemporary accounts, see Robin Hyde's Nor the Years Condemn (1938) and John Mulgan's Man Alone (1939).
} 
People who had formerly been pillars of respectability soon lost it in the struggle to exist, and I saw tradesmen chipping weeds on street corners and cleaning gutters. (22)

The results of the Depression on some people were very distressing. I can recall a person who was a head man in the primary school which I went to. His people had a little business but because he couldn't get any work - and he was out of work a lot, longer than I was - he took to thieving and ended up in jail. (32)

[...] I took in this bloke who was actually on relief. He always paid his rent on the dot so I didn't have any complaints but I was in his kitchen one day and I saw into his cupboard and it was absolutely packed with food. All sorts of tinned stuff, and sugar and stuff [...] I found out later that he had a friend in the relief depot and there was quite a racket going. (74)

Bread and dripping was the thing. Butter, I think was 1 shilling a pound and this was a fair bit. I'm not sure but I think dole was 15 shillings a week or something like that for a married man. Well, a shilling for a pound of butter was a fair portion of that. Imagine today spending one-fifteenth of your income on butter! (18)

The Depression was greyness. That's a physical reaction. It's the only way I can describe a sort of hopelessness that seemed spread around people who, in the earlier parts of their lives, had been accustomed to security. (16)

I know one disgraceful situation where there used to be a railway development and people were building cuttings and putting fill into the gullies. This was stopped because it was public works [...] But the men were there and the Works Department was giving them relief work [...] They had a lot of rubbish, logs and clay and stuff to shift, so they said to the men, 'Shift this,' and it was shifted over to where the engineers indicated. Then the problem was what to do? The engineers looked around for other work and there wasn't any so they said, 'Shift it back again.' [...] You can't conceive of a worse form of degradation. (93)

Queen Street was looted from end to end. Law and order were down and out. Men were being marshalled from the navy to patrol the streets. The looters, being ordinary citizens moved to desperation by distress, exploded in violence and then just as suddenly disappeared [...] although they would gather in Karangahape Road for a repeat the next night. (121)

[...] there was a knock at the door and it was a swagger. He asked if we had anything to eat. The old man brought him in and put a tablecloth on the table, set him a place and went to the cupboard [...] I recall him cutting the last of the meat off the bone; there were a few spuds left over, peas and stuff like that. He piled it up, gave the man a bit of bread and this chap ate everything [...] When the old woman got home [...] she tore strips off the old man and accused him of taking food out of the kids' mouths and giving it to some stranger, some bum - well, he just sat there and he took it, he never said a single word. (21-22) 
Gee's portrayal of Loomis during the Depression captures the anxiety of that period and the conditions that led to social violence: "They were hard times. They were hungry times" (9). The town's physical decline, measured literally by the boarded-up shops in the main street and symbolically by the decrepitude of elderly Mrs Muskie, is matched by the breakdown of its social structures. Poverty has levelled out the class distinctions in Loomis (the Muskies, once considered "nobs" (53), are now as poor as the rest of the townsfolk) and reduced people's lives to survival level. As the story's narrator tells us, "nobody was important now, not in Loomis. Most people were broke and most of the men were on relief' (21).

Humanity has no part in the character of Loomis (although we do see it in the Potter family's dealings with each other). Gee depicts Loomis as a town dehumanised by the effects of the Depression (and, symbolically, by Muskie). Stripped of humanity, then, and the normal ordering structures of society, Loomis reveals the dark side of its psyche and turns to social violence. Old Flynn, suspicious of trespassers, shoots at anyone crossing his orchard. Pathetic Mrs Muskie is neglected by the community: "Only one or two of the other old ladies in Loomis spoke to her, and not for long" (23). ${ }^{37}$ Some of the townsfolk ignore prohibition and buy illegal alcohol from Muskie's sly-grog shop. The Potter men are drawn into lawlessness, Laurie for the money and Grandpa for the excitement. Muskie himself, already predisposed to crime, commits burglaries and receives stolen goods. Even Colin transgresses. Motivated by greed, he steals Muskie's chocolate bar and justifies his action as being "rent" (13) for the hut. Loomis does eventually return to some normality as social order is restored after the death of Muskie and as "times improved" (141). Free of its two oppressors, Muskie and the Depression, the town can now exercise its choice for good (just as $\mathrm{O}$ can after Susan has restored the Balance in Gee's The Halfmen of $O$ ).

\footnotetext{
${ }^{37}$ Neglect has been defined as "a form of abuse" (Ritchie and Ritchie, Violence in New Zealand 69).
} 
Social violence in Loomis can also be seen as a response to the internal force of puritanism, a topic introduced in chapter 1 of this thesis. In its New Zealand context, puritanism has been defined by Lawrence Jones as "a secularised pattern of feeling and conduct" ("Puritanism" 455) typified by the work ethic and a rigid code of behaviour. More often than not, states Kirstine Moffat in her excellent PhD thesis, "The Puritan Paradox", "[p]uritanism is viewed as a negative social influence, a harsh, repressive, destructive creed" (20). Bill Pearson, for instance, decries puritanism as "a contempt for love, a sour spit, a denial of life itself" (27) and Gordon McLauchlan condemns it as "anguished selfflagellation" (17). Moffat dismisses such descriptions of puritanism as "inadequate and distorting" (402) and refreshingly argues for it as a "radical/conservative dichotomy" (ii).

Nevertheless, the negative view of New Zealand puritanism is probably the one that has been more widely held by New Zealand writers, social historians and literary critics. This is a view that Maurice Gee shares, and one that he critiques in this novel. Quite where this negative view comes from is unclear. It could be a legacy from the settler mentality when, in Moffat's words, "[t]he puritan ethic of hard work, frugality, and self-reliance was vital for success in new settlements" (15). Or perhaps there is something dark in the New Zealand psyche that likes to flagellate instead of celebrate.

What is clear from the biographical account in chapter 1 of this thesis is that Gee experienced the repression of puritanism as he was growing up, from his mother's puritan idealism to what friend and poet Kevin Ireland describes as the "merciless puritan rigidities of the age" (qtd. in Brett 96). Gee has acknowledged his awareness of how "puritanism can cripple and even destroy" (qtd. in Brett 99), and expressed relief that "the dreadful Puritanism that crippled so many of us has gone" (qtd. in Holloway 24). Yet the shadow of 
puritanism hangs over his writing, confirming its continuing influence on him and on the development of the New Zealand character.

In The Fat Man we find the negative effects of puritanism entrenched in the town and at the school. Despite its well patronised five churches, Loomis is a judgmental town. The townsfolk, like Pearson's New Zealander in his classic essay "Fretful Sleepers", are ready to "defame or ascribe disreputable motives" (Pearson 10) to anyone who does not fit in. We do not meet these critics. They are referred to collectively and anonymously in the text - "the local men" (22), "the returned men" (22), "people say" $(27,51)$ - but their slander and malicious gossip adversely shape Loomis opinion in what can be seen as a form of social violence. The returned (service) men, for instance, say Herbert Muskie "used his fat $[\ldots]$ to get out of the army" (22), while people claimed that Mrs Muskie was so miserly "she wouldn't hire a man to cut the grass or a woman for the washing and ironing" (22). And at school, a microcosm of Loomis society, authoritarian attitudes towards the socialisation and control of children result in corporal punishment and bullying for those who do not conform.

Corporal punishment, the legitimate use of force at school by teachers acting in loco parentis to correct or punish students, is an agent of social control at Loomis school. Its practice there (a practice abolished in New Zealand schools since 1990) parallels the punitive nature of New Zealand's educational institutions since the mid-nineteenth century and the inequality of a system that empowered teachers and disempowered children. For two generations, 'Itchy' Edgar's pupils have had the expectations of a "norm-ridden society" (Pearson 14) beaten into them. At school, as at home, children must speak only when spoken to, do what adults tell them to do and behave properly at all times. If they do not comply with these social norms, they get the 'cuts'. 
Gee shows the harmful effects of corporal punishment across two generations. Verna, who has only had "a wee tap" (58) in the form of punishment from her mother, is strapped for spitting and nurses her red palm all afternoon. The tough girls receive two 'cuts' each for bullying Verna and retaliate by continuing to bully her for a week. Twenty years earlier, 'Herbie' is strapped every day for a year for farting in class, something he says he did not do, and later enacts a violent revenge on the adult Pottsie (Laurie) for setting him up. But, as the next paragraph suggests, young Muskie's unjust treatment may be as much an indictment of the town's intolerance of difference as it is of the sanctioned culture of violence at school.

In "Fretful Sleepers", Pearson writes, "There is no place in normal New Zealand society for the man who is different!" (6). The social implications of Pearson's critique of attitudes to difference in New Zealand society resonate in Gee's Loomis, especially at school where children who deviate from the norm are bullied. Herbie is fat and his family are "nobs" (53). He is fastidious, compliant and quick to cry, qualities that may be perceived as more feminine than masculine. These differences make him an attractive target for bullies, including his teacher who colludes with them. Ironically, Herbie's passive acceptance of the roles of victim and scapegoat feeds the bullying. "I never was a stoolie" (134), he tells Colin. So Pottsie's gang has "a bit of fun” (62) with him that includes taunts, victimisation and attempted drowning, and the girls laugh at him in his swimming togs.

A generation later, Verna is bullied by the tough girls at school because she is different: "We don't like kids with no hair [...] And dresses and pink bows and shoes and stuff. Or skites who come top of the class" (81). Once she starts to look more like them her hair grows and she sometimes goes barefoot - the girls leave her alone. Colin is beaten 
up by the Settlement gang for telling on the girls who bullied Verna: "Usually they left him alone because he was good at football and cricket, because his father had been a boxer too. But pimping changed all that" (83). After that score is settled, Colin reverts to his pacifist self and the gang loses interest in him.

Bullying is an accepted practice at Loomis school and Gee depicts it as both selfperpetuating and damaging. Teachers bully children and that behaviour is replicated in the anarchy of the playground where the gangs prey on the weak and the vulnerable. Gee himself remembers the school playground as "a fairly desperate place" (qtd. in Holloway 22) and, with shame, once being part of a gang that mercilessly bullied the school fat boy (“Beginnings" 288, "Creek and Kitchen” 89). Being a victim of chronic bullying has left Herbert Muskie emotionally scarred and socially maladjusted. Perversely, it has also equipped him with the psychological tools he needs to be a bully. 'Herbie's' coping strategies - submission and tears - only serve to further encourage his tormentors. In what could be seen as a warning of the long-term damage caused by bullying, at the end of the novel a fearful Muskie regresses to "the fat boy again, running from the playground gang at Loomis school" (138).

For Verna and Colin, the bullying is frightening but short-lived. Although they accept with some fatalism the rough treatment of the playground bullies, they appear to have better coping strategies than the young 'Herbie'. Verna learns to fit in and Colin knows to keep his head down. While Gee says that "[The Fat Man] is not a book about bullying" (qtd. in Nieuwenhuizen 4), bullying is part of the story and, unfortunately, part of life. Removed from the concerns of everyday life and distanced by time and place, this historical novel may be a safe place for young readers to consider how they might deal with bullying in their contemporary world. 
As we have seen through the character of Herbert Muskie, individual violence has many representations. The perpetrator of the violence, Muskie manipulates, influences and controls his victims across a range of situations. He continues to be dominant in the wider family setting, using the relative privacy of home to extend his power over Bette, Verna and his mother. In that setting, family violence means discipline and order for the Potters, whereas for the Muskies, it is a means of control and subjugation. Within the wider social context, however, Muskie's influence is slowly eroded and he ultimately becomes a victim.

But the pattern of violence remains the same, although its form may not. Violence spreads insidiously from the male perpetrator to the family unit and then into the community where its influence and potential for damage are greater because more people are affected. Thus we see the adverse effects of the socially condoned practice of corporal punishment at school and the playground bullying. Violence, then, is represented in this novel as an expanding and damaging force across multiple levels of society. 


\section{Chapter 4}

\section{Social Violence and the Post-War Novels}

While violence retreats as a primary theme in Maurice Gee's last two historical novels for children, Orchard Street (1998) and Hostel Girl (1999), it nevertheless runs through these texts as a strong undercurrent in the form of social violence. This chapter, then, continues the exploration of social violence begun in the chapter on The Fat Man but instead of focusing on town and school as sites of that violence (as we saw in The Fat Man), the interest here is at the microlevel of street and suburb. Set in New Zealand during the conservative 1950s, Orchard Street and Hostel Girl portray convincing versions of the civil and social unrest at that time and position social violence as both a response to that unrest and a reaction against existing forces in society. Although the historically important 1951 Waterfront Dispute and 1954 Mazengarb Report frame the novels and feed into their narratives, the author's concern is less on retelling history than on the interaction of his protagonists with their families, their neighbours and their communities during those years.

Social violence is part of everyday life in both these novels. It is defined in this chapter in two broad ways, following on from its 'catch-all' description in chapter 3. First, it is a general term for acts committed by individuals or groups that impact adversely on society such as the gossip and crime we see in Orchard Street. Second, it describes the impositions on people's behaviour by society's structures and norms such as the religion and morality depicted in Hostel Girl.

\section{The implied reader}

Unlike the novels discussed so far in this study, Orchard Street and Hostel Girl are young adult novels. Their implied reader is older than the implied reader of the earlier 
novels who would be aged 7-13, and in what J.A. Appleyard calls "later childhood" (57). Older readers in later childhood, says Appleyard, that is, 10-12 year olds, particularly like "historically realistic stories" (60) and stories where "character becomes more important than action" (87). These descriptions would certainly fit The Champion and The Fat Man. More specifically, Norma Schlager found the most popular books for this upper age group were those that matched the readers' developmental stage. Books, in other words, that "dealt with the intermediate realities of the older child's world: how to manage being independent, making decisions, and solving problems" (Schlager, qtd. in Appleyard 88). As demonstrated in his earlier novels for children, particularly in The Fat Man where incest and domestic violence are implied, Gee's approach to adult themes in his children's fiction is to keep the story "on the level of a child's understanding" (qtd. in Holloway 22). In Orchard Street and Hostel Girl, however, Gee deals quite directly with adult themes - sexuality and morality- and his protagonists are relatively worldly thirteen to nineteen year olds. The implied reader of these novels, then, is a young adult (around 13 years and over) who will identify with these protagonists and their situation.

\section{Orchard Street}

Orchard Street is a coming-of-age story about 13-year-old Austin Dye (also known as 'Dinky' or 'Ossie') set in 1951, the year of the waterfront dispute in New Zealand that ran for 151 days and divided the nation. The story's narrator-protagonist is the older Austin who, 40 years after the dispute and in the voice of his younger self, describes how that year changed his life. (The nickname 'Ossie' is very close to Gee's childhood nickname 'Mossie' and may suggest a special affinity between Gee and his character.) Although Ossie is aware of the waterfront dispute and can parrot the views of his staunchly Labourite parents - "workers against ship-owners, workers against Slippery Sid" (9) - to him the 
dispute has a family, not a national significance: "Us against them" (9). That "Us against them" mentality pervades the novel at both the microlevel of the street and the macrolevel of society.

\section{Sources and influences}

Once again Gee draws on his Henderson childhood to locate and populate his novel: "My town again, if not my childhood times. But definitely my street, and the people of my street" (“Creeks and Kitchens" 23). Passages from his autobiographical accounts and his 2002 Margaret Mahy lecture vividly describe Newington Road where he lived as a child, its location and layout, its occupants and their idiosyncrasies - details that map closely to the fictional Orchard Street in Loomis. Gee's Pinckney neighbours, for example, who "sewed tents for a living" ("Beginnings" 285) become the story's tent-sewing Redknapps; Mr Hart, "the old man down the street who died from grief shortly after his little dog was run over by a car" ("Creeks and Kitchens" 23) becomes Mr Worley; and the Kays (she was a Radiant Living exponent), the Scotts (he bred budgies and built kites) and the Greenhoughs (he was a railway signalman) (“Creek and Kitchen" 85) are conflated into the joyless Pikes.

Less personal sources would have acquainted Gee with the waterfront dispute, necessary research because it had apparently passed him by as a young man (Manhire 6). Two early accounts he may have read are Dick Scott's contemporary 151 Days (1954) and Michael Bassett's retrospective Confrontation '51 (1971). Research has also allowed Gee to include in the novel historical figures who played pivotal roles in the dispute itself "Slippery Sid" (Prime Minister Holland), Mister Barnes and Mister Hill (leaders of the wharfies), Goosman (a government minister), Mr Nash (the Labour Party leader) - which adds to its sense of realism. 
Gee brings to Orchard Street his personal beliefs in socialism and humanism. These beliefs were alluded to in chapter 3 of this thesis, which sees him described as a "true socialist" (qtd. in Brett 101), and in chapter 1, where he calls himself an "atheist humanist" (qtd. in Smithies "Maurice Gee"). Through his characters and their interactions with one another, Gee appears to be making a statement about the importance to society of socialist values such as community, cooperation and equality; and humanist values such as tolerance, responsibility and rationality compared with individualistic values such as self-interest and private enterprise. ${ }^{38}$ As I shall argue, these competing values inform Gee's portrayal of social violence in the novel and reveal where his sympathies lie in Orchard Street itself and in the wider national dispute.

\section{Social violence in Orchard Street}

Outwardly, Orchard Street is an ordinary street where ordinary people live. Yet beneath its benign surface runs an undercurrent of violence. Mr Raffills has beaten his sons with tomato stakes and been locked out of his house. Mr Cooper gives his wife black eyes which she says have come "from walking into the door" (23). Angry Mr Pike released his budgies and "little coloured birds were flying all over Orchard Street for days until they died" (22). And "nutty" (26) Mrs Redknapp threatens to ring the pound and get Jimpy put down for fouling the lawn. The neighbours, in fact, are not very neighbourly at all and tend to act out of self-interest rather than cooperatively.

There are two types of social violence that further disrupt the pattern of everyday life in Orchard Street. Gossip negatively impacts on neighbourhood opinion in Orchard Street

\footnotetext{
${ }^{38}$ For definitions of these terms see Heywood 102-111, 130, 28.
} 
just as it did on Loomis opinion in The Fat Man while crime is a feature of both novels but committed for different reasons.

\section{Gossip}

Gossip is the street's common denominator and an insidious form of social violence arising from within a judgmental society. (Here I refer back to Pearson's essay 'Fretful Sleepers', first mentioned in chapter 3, and his New Zealander who is ready to "defame or ascribe disreputable motives" (Pearson 10) to anyone who does not fit in.) It is not an activity that advances the ideals of community or tolerance. Rather, the gossip is idle or malicious talk about the personal or private affairs of others. Despite the 'unneighbourly' neighbours, everyone in Orchard Street seems to know everyone's business. Mr Redknapp has been gassed in World War I and Mrs Redknapp is severely depressed; the Collymore house was "going to pot" (44) since Mrs Collymore died; and Mr Worley has sold the land his orchard stood on to a speculator. Ossie, particularly, knows the personal history of all the neighbours "from stories I'd heard from Mum" (21) and accesses their private lives by spying on them. When Teresa is sick, he 'treats' her with the street gossip: "Mrs Cooper had run away with the painter who had come to paint her roof, and Mrs Pike had boils in spite of vegetables, and Bike had told Les not to swear in front of ladies" (93). But gossip turns into judgment when Frank Collymore and Eddie Dye are arrested. Like a Greek chorus, the neighbours collectively imply disapproval by "pursing their lips" (9) and, in the aftermath of the shooting, stand "leaning inwards at each other, whispering" (130). 


\section{Crime}

There are three crimes committed in Orchard Street in 1951 that can be described as social violence as defined in this chapter: printing illegal material, bookmaking and shooting with intent. Although they are very different crimes, all three result in their offenders being taken away by the police. I will discuss the crimes of Eddie Dye and Frank Collymore first because they seem to best illustrate the competing values at play in the street and the wider society mentioned earlier in this chapter.

\section{$\underline{\text { Printing illegal material }}$}

Eddie Dye, printer and unionist, is a socialist. His crime is printing and distributing pamphlets advocating the wharfies' cause in the waterside dispute. It is a political crime likely to result in prison with hard labour if he is caught, but a crime his strong socialist principles of community and equality lead him to commit and that his wife fearfully supports. Eddie's fight is against capitalism and fascism, which he sees as personified in Sid Holland and embodied in the Emergency Regulations. Exemplifying the socialist principle of cooperation, Eddie's crime becomes "a family thing" (11). Lil types up the handwritten propaganda, Eddie prints it and his sons deliver the Loomis pamphlets, the latter a dangerous job that Eddie considers "part of their [socialist] education" (12).

Eddie is also a humanist. He is tolerant of Les' hedonistic ways, saying 'He just thinks life's a joke. He'll learn" (52). But he does not like printing the 'flat beer lists' and 'rolls of dishonour', seeing the humanity in each name: 
Now and then he came across the names of men he knew and that brought them up close, it made them real, he said. "You can't just yell scabs at them as though they've got no faces. You've got to say Jim Smith and Joe Brown, and maybe they're weaklings but they're just trying to keep their families fed." (Orchard Street 69)

Instead Eddie would rather print leaflets that balanced the pro-government reports of the dispute with the pro-union account. An official report might say ten wharfies had been hospitalised after a fight with police. Eddie's leaflets would say that most of the injuries were from police batons.

Eddie is a pacifist, almost certainly influenced by his experiences in World War II. When Les half-jokingly threatens to shoot Sid Holland, Eddie reacts quickly: "Don't you talk about shooting in my house. I've seen men shot. It's not a game. You end up dead" (52). Eddie's words are prophetic but it is Bike who ends up shooting and Les who almost gets killed. Ossie expounds on Eddie's pacifism later in the story: “[Dad] doesn't want to fight anyone, not with guns. He says guns are for lunatics. And uniforms too. And all that saluting and stuff. [... ] He just wants to fight with common sense" (72). The words 'common sense' are quite a close synonym for 'rationality', one of the values of humanism. That Eddie is arrested on July 7 1951, the same day that Jock Barnes, president of the New Zealand Waterside Workers' Union, was jailed for 'defaming' a constable (Grant, The Big Blue 187), seems more than coincidence. Gee may be seeing a Barnes-like figure in Eddie Dye. Thus Eddie seems to represent the socialist and humanist values that Gee himself holds and, perhaps, believes society needs. 


\section{$\underline{\text { Bookmaking }}$}

In contrast, Frank Collymore is an individualist; his crime the socially condoned practice of bookmaking. ${ }^{39}$ Social historian Redmer Yska notes that Sid Holland's National Party came to power in 1949 "on a platform of defending personal freedom and championing private enterprise" and tapped into "a go-getting individualistic mood, in contrast to the solemn, collectivist spirit of the previous decade and a half" (Yska, "Spies, Lies and Red Herrings" 24). Self-employed and a believer in the free market (which he capitalises on by working as a bookie), Frank seems to embody that spirit of personal freedom and private enterprise advocated by Holland's party. Yet his cartage business is just a front for his profitable (and illegal) bookmaking business. Unlike Eddie who travels into Auckland to work, Frank's office is his kitchen table where he sits "taking bets on the phone and writing them in a school exercise book" (37). While Eddie must supplement his income by doing small printing jobs at home, Frank earns enough as a bookie to buy a new Humber (and to pay thousands of pounds in tax arrears when the tax department catches up with him).

Frank is a self-centred man. A Catholic in name only, he is apolitical and not interested in union matters -"union hoo-ha" (33), he calls them. His interests are parochial: "drinking beer and going to the races and kidding with women" (33). The drinking leads to Jimpy's death when Frank, driving drunk, runs him over, and the kidding can get him into trouble:

He used to call out to [women] from his truck, 'Gidday, gorgeous', and blow kisses and offer them rides, even when he'd never seen them before. That sort of behaviour was frowned on in the 1950s, although not as much as it is today. Some people admired Frank and said he was a dag. (Orchard Street 33)

\footnotetext{
${ }^{39}$ Bookmaking had been illegal in New Zealand since 1911, although the practice continued covertly (Belich 316).
} 
This behaviour may be an expansion of Frank's unlimited sociability - as Eddie says, "Frank would say cobber to the king" (90) - or, less kindly and in a more contemporary sense, an expression of his sexist attitude towards women.

Frank's selfishness extends to his family. He neglects his seriously ill wife, passing on her physical care to his daughters and her spiritual care to the Catholic Church. (We are reminded here of Mrs Muskie's sad neglect by her family and town in The Fat Man.) Given Frank's laissez-faire character, there may be some truth in Lil's sharp comment that "I think [Mrs Collymore's] more sorry than sick, with that husband of hers" (36). After his wife dies, his daughters have to run the household while his sons run wild. Frank, it seems, puts women into one of two categories: sexual object or servant. For Gee, then, Frank may represent individualistic values that are not only damaging personally but also nationally.

Gee depicts Eddie and Frank as opposites, individually and ideologically. He paints a sympathetic picture of Eddie as a man with a social conscience and a concern for his fellowmen, and Frank more critically as a self-serving man with little insight into his own behaviour. $^{40}$ Eddie's crime is the greater one in the context of the dispute but his punishment (a £100 fine) is much less than Frank’s. Perhaps this is because the dispute is over, but it could also imply Gee's support for Eddie's stand and, indeed, of the view that individual action is sometimes necessary in defence of the greater good. There is no greater good in Frank's case, only self-interest. Frank's double punishment - the fine for bookmaking and subsequent investigation by the tax department - may be seen as poetic justice for his individualist ways. Through Gee's tacit approval of Eddie's socialist and humanist values (and Gee's consistent use of the word 'lockout', not strike, to describe the

${ }^{40}$ Gee often invests his characters' names with meanings beyond the literal. Just as the Wilberforce name in Under the Mountain contains the essential characteristics of the creatures, that is 'will' and 'force', so might the 'more' in Frank's Collymore surname reflect his selfish nature. 
catalyst for the dispute), we can infer that the author's sympathies lie with the workers and families affected by the waterfront dispute, not the government.

\section{$\underline{\text { Shooting with intent }}$}

Ian ('Bike') Pike's crime - shooting with intent - is the most serious of the three crimes that occurs in Orchard Street that year, and he is sent to prison for it. Initially, Bike demonstrates positive socialist and humanist values. He values community and cooperation, playing in a local rugby team and participating in the inter-secondary school sports. Furthermore, he is friendly and courteous, inviting Ossie to join a Joan Leslie fan club and engaging in polite talk with his bank customers: "It's a nice day, madam. Thank you, sir" (48). Bike treats women with an old-fashioned gallantry. At dances, he asks, "May I have the pleasure of this dance, Miss Collymore?" (55), and takes to the floor "with lots of fancy stuff, long steps that made Eileen look graceful too, and swirls that seemed to take up half the floor" (55).

Despite the gallantry, Bike is a conflicted character - outwardly controlled and inwardly volatile. Over-mothering and the Radiant Living religion his family practises contribute to his inner turmoil. ${ }^{41}$ Early in the novel, Ossie observes that, "although [Bike] wasn't popular no one bullied him or left him out" (22). Yet bullying and excluding are exactly what Ossie and the others do when they repeatedly rebuff Bike's attempts at friendship. Treated as "a bit of a joke" (22), Bike becomes a loner, increasingly isolated from his peers - and from reality. His unhealthy obsession for Eileen Collymore, whom he has idealised as 'pure', leads him to stalk her and eventually shoot her in a moment of

\footnotetext{
${ }^{41}$ Radiant Living was a spiritual movement active in New Zealand between the late 1930s and late 1980s. By regarding people as beings with three dimensions - body, mind and spirit - it was believed that health and happiness could be gained by diet, physical fitness, positive attitudes and spiritual awareness, and by following nature's laws (“Herbert Sutcliff - Radiant Living”).
} 
passion (anticipating Errol Parkinson's similar but more final trajectory of violence in Hostel Girl). But Bike gets a sympathetic hearing from Mr Redknapp and advice on facing the consequences of his actions - up in the pine tree they both occupy until Bike relinquishes his gun.

Bike's divided nature, however, is more than Jung's split psyche of ego and shadow. It is also emblematic of divisions in the street and in the waterfront dispute itself. Perhaps in Bike Pike is a lesson of what could happen in society if socialist and humanist values are discarded in favour of individualism.

As we have seen throughout the novels studied in this thesis, Gee's protagonists demonstrate the mixed nature of humanity. They are 'mixies', not entirely bad and not entirely good. The same is true of the characters in Orchard Street. So the Eddie I have argued is a template for socialist and humanist values places his bets with a bookie while Frank's self-centredness is replaced, briefly, by fatherly concern over Eileen's injury. This mixed nature of humanity continues in Hostel Girl, where some of the themes introduced in Orchard Street are advanced.

\section{Hostel Girl}

In November 1954, the Report of the Special Committee on Moral Delinquency in Children and Adolescents was posted to every household in New Zealand (Yska All Shook Up 81). This report, commonly known as the Mazengarb Report after its chairman, Dr Oswald Mazengarb, had been commissioned by the government in response to a moral panic about sexual immorality in New Zealand juveniles. ${ }^{42}$ Relying on unsubstantiated evidence, the

\footnotetext{
${ }^{42}$ Whether it was a moral panic or not is disputed. See Belich 505 and Brickell 475.
} 
report concluded that there was a "new pattern of juvenile immorality [that was] uncertain in origin, insidious in growth, and [that] has developed over a wide field" (Mazengarb 59). The report identified many causes of this "evil" (Mazengarb 17), including the home environment (especially working mothers) and what it called 'moral drift' (Mazengarb 42), or society's move away from a religious-based standard of conduct. Also singled out were media influences such as objectionable publications, films, broadcasting, advertising and television. As a result, legislation to deal with the perceived problem of juvenile delinquency was hastily passed through parliament (Shuker and Openshaw 19).

Public concern about adolescent rebellion had been steadily increasing since the early fifties. In 1953, there was an outbreak of school-age sex in Lower Hutt and reports of illicit sexual activity associated with Elbe's Milkbar in High Street. This was followed by the Parker-Hulme murder in 1954 where two Christchurch schoolgirls bludgeoned one of their mothers to death with a half brick wrapped in a stocking. Then in 1955 a teenager was fatally stabbed in an Auckland milkbar. Running parallel to these incidents were two influences widely regarded as damaging to adolescent morality: American mass culture in the form of pulp fiction (including comics), film and rock and roll, and an emerging teenage subculture that was strongly influenced by overseas forms and fads. These relatively isolated assaults on the established order led to the Mazengarb Report and a period of moralistic censorship in New Zealand. ${ }^{43}$

This, then, is the historical background that shadows Hostel Girl. Set in suburban Hutt Valley during 1955, the story is a psychological thriller about 14-year-old Ailsa and her boyfriend Calum who try to identify the man who is stalking her friend, Gloria. Yet, in another sense, the novel reads as a commentary on New Zealand society after the

\footnotetext{
${ }^{43}$ This summary of the social unrest in 1950s New Zealand is drawn from Belich 504-507; Yska, All Shook Up 58-68; and Brickell 473-475.
} 
Mazengarb Report with Gee presenting Ailsa as a corrective to the report's claims of teenage immorality and violence. That the characters are aware of and reference the ParkerHulme murder and the Mazengarb Report in the novel suggest the importance of these events as narrative devices, not just history. Ailsa, for instance, makes a connection between Gloria's wish that her father were dead and "those girls in Christchurch [who] had killed one of their mothers with a brick" (21), and Mrs Page tells her husband that she does not like Calum going out with Ailsa because she is "straight out of the Mazengarb Report" (109).

\section{Sources and influences}

Gee has described his primary source for Hostel Girl as "impeccable" ("Creeks and Kitchens" 23). In a departure from his usual practice of mining his childhood to furnish his novels, Gee has drawn on his wife's schoolgirl diaries to provide authentic settings and cultural references for the novel. As he told Denis Welch:

Margaretha lived in the Woburn hostels for three years when she was 14-16. Her mother was a matron of what was known as House 4, which housed the dental nurses. She has mentioned it from time to time, but the great favour she allowed me was to let me read her schoolgirl diaries which she kept for three years. And the whole hostel background is there. It was all there: the books she was reading, the movies she was going to, her friends, the sport she played - all that sort of stuff was in these little diaries that she kept. (Qtd. in Welch 58-59)

Margaretha's diaries also provided Gee with the geography of the Hutt Valley in the 1950s - Woburn station, Hutt Recreation Park, Chilton St. James School (Willowbank in the novel), Elbe's Milkbar, Griffin's factory, Prince Edward Theatre and so on. Importantly for the author, the diaries gave him the opportunity to write solely from the female perspective, something he had not done in his children's fiction before. Through Ailsa's 
eyes we get an impression of what life was like for women in the 1950s, which was very different for women in the late 1990s when Gee was writing the novel. By the late 1990s, second wave feminism had won significant gains for women. In 1999, for example, women held or were about to hold New Zealand's top four political and judicial positions (Belich 497-498). Thus it is possible to see in Gee's depiction of his feisty protagonist the beginnings of feminism, a theme he pursues more rigorously in Ellie and the Shadow Man (2001), his adult novel developed from Hostel Girl.

The diaries would not have been Gee's only sources. He would have been familiar with the Parker-Hulme case and the Mazengarb Report, both of which featured heavily in the newspapers of the time (Shuker and Openshaw 21-30). It is highly likely that he would have read a copy of the report because, as stated above, it went to all homes in New Zealand. And given Gee's self-admitted obsession with "the human capacity for cruelty and inflicting pain on others" (qtd. in Brett 99) he would have seen Peter Jackson's Heavenly Creatures (1994), a film about Juliet Hulme and Pauline Parker, and used it as a background source for Hostel Girl.

In what follows I will discuss religion, social class and morality as examples of social violence in this novel. Social violence was positioned in the introduction to this chapter as both a response to civil and social unrest and a reaction against existing forces in society. Religion, social class and morality are existing forces in society which impose on people's behaviour. This imposition can be seen as a form of social violence. 


\section{Religion}

As an atheist humanist, Gee does not believe in religion. Throughout his children's novels, however, he exposes what he sees as the hypocrisy of religion and religious organisations. There is no 'good priest' in any of these novels. In The Fire-Raiser, for example, Mrs Bolton is depicted as a religious bigot "fighting for Christian behaviour, right belief of every kind" (25) while in Orchard Street, the tenets of Catholicism and Radiant Living are contradicted in Frank Collymore and the Pikes respectively. Frank has turned his back on God in favour of earthly pleasures and Mr and Mrs Pike are embittered by Radiant Living, despite the songs they sing "that sounded like hymns of the cheerful sort or marching songs" (21). Encoded in The Priests of Ferris is, perhaps, Gee's most explicit criticism of religion. In an ironic allusion to Christianity, Gee describes how the cult of Susan "made a holy book, it set up rotes and doctrines and invented enemies, and people flocked to it, and soon it ruled" (59). What follows in $\mathrm{O}$ is, in effect, an allegory of the harm Catholicism and Protestantism have done in the name of religion over the centuries: sacrifices, holy wars, corruption, killing, prohibitive laws, persecution, torture and lies. Religion and its trappings, Gee seems to say through his character the High Priest, are "mumbo-jumbo" (The Priests of Ferris 133).

Religion plays an important part in Hostel Girl, too, although it is not always an obliging force. The hostel Ailsa lives in is run by the YWCA, a non-denominational Christian organisation for young women, the young women who board there belong to a number of denominations and Ailsa goes to a private all-girls' school run by the Anglican Church. Where Gee contrasted Catholicism and Radiant Living in Orchard Street, in Hostel Girl he contrasts Catholicism and Protestantism. Neither denomination escapes his critical eye, as the following vignettes show. 
Gloria ("Glorious") Wood is a nominal Catholic, a glamorous trainee dental nurse escaping from Stratford, "where the grass grows. And nothing else" (21). She is a rebellious girl who smokes, swears and wants to have "some fun" (20), probably in reaction to being brought up in a strict Catholic household dominated by an authoritarian and abusive father. Gloria wears her religion lightly until she thinks she is pregnant and the teachings of the Catholic Church about the sanctity of life come back to haunt her in the form of guilt and fear:

[...] Gloria turned her face, tear-stained. "You don't understand. I'm a Catholic."

"I know."

"So ... doing things like ... taking stuff, it's a mortal sin. I'd go to hell." (Hostel Girl 99)

Through Gloria (and lapsed Catholic Frank Collymore in Orchard Street), Gee depicts Catholics as tolerant and non-proselytising and, by implication, Protestant fundamentalists as narrow-minded and preachy:

“Aren't you religious?” Ailsa said.

"I'm a Catholic. We don't go around trying to make other people feel bad." (Hostel Girl 20)

Gloria's response is a direct criticism of the smug Protestant fundamentalists at the hostel. It may be Gee's view too, as in the past he has criticised fundamentalist sects (and mainstream churches) for indoctrinating children (Gee, qtd. in Holloway 24). What is also interesting about this brief conversation is the distinction Gloria makes between being 'religious' and being a 'Catholic'. It appears that, in Gloria's mind at least, one can be a Catholic without being 'religious' (in the fundamentalist Christian sense of the word). Ailsa, however, only differentiates between those who are 'religious' and those who are not. 
Betty Briggs is equally bound by her Protestant fundamentalism and may represent the moralistic sector of society after the Mazengarb Report. She is self-righteous with a puritanical view on sex, swearing, wearing make-up and having fun. When Gloria puts on her lipstick, Betty shuts her eyes, presumably so she does not see the devil's work.

[...] Betty was religious and prayed each night, kneeling by her bed. It embarrassed Ailsa. She didn't know where to look. And Betty told her she'd rather she didn't swear, when all Ailsa said was 'damn' under her breath.

"I was talking to myself," Ailsa said.

"I heard. And so did Jesus. (Hostel Girl 7)

Ailsa's response to Betty's zealous religiosity and her avoidance of the Christian girls' table in the dining room indicates her lack of interest in religion. But Divinity is a core subject that all girls must take at Willowbank School. Ailsa "liked Divinity - the parables and stories and moral lessons fitting in with them; but didn't like the lessons without the stories - what Mrs Nimmo called the humbug side of religion" (9). The word "humbug", which means "deceptive or false talk or behaviour" ("Humbug"), strongly suggests the hypocrisy of religion. This is one of Gee's views, expressed through his mouthpiece, Mrs Nimmo.

While these descriptions are limited and possibly stereotypical portraits of Catholicism and Protestantism, they serve to illustrate how religion can impose itself on people's lives - women's lives in this case and their choices regarding reproduction, sexuality, morality and faith - in a way that may be seen as unjust, repressive and hypocritical. 


\section{Social class}

Andrew Heywood defines social class as "a social division based on economic or social factors" (108). It is a division that can be as damaging and restricting as religion on people's lives. In Hostel Girl, socioeconomic differences are represented literally on opposite sides of the railway track - the working class on the eastern side and the upper middle class on the western side. The McGowans are unapologetically working class. Ailsa's father had been a Glaswegian boilermaker who migrated to New Zealand in the Depression, married Ailsa's mother and was killed in Crete during World War II. Mrs McGowan works at two jobs, one as a pay clerk at Griffins and the other as matron of House 4 of the YWCA hostel in Woburn: "Being a matron after her day job tired her out, but what was a widow to do?" (6).

The Pages have all the trappings of the wealthy upper-middle class: two cars, a yacht on a trailer, a large house with picture windows and a grass tennis court. Inside the house, " $[\mathrm{t}]$ hingy things were everywhere $[\ldots]$ porcelain figures and wired-up plates that were neither beautiful nor useful" (31). Genial Mr Page is a partner in the family law firm, snobbish Mrs Page has never worked (unless amateur theatricals count), and "boy-mad" (10) Helen attends Willowbank School with Ailsa. Calum Page, Helen's older brother, has suffered elitism in reverse. His once-devoted mother is ashamed of him because he has had polio: "People like us don't get polio, it's working class" (51).

In Ailsa we can see an attempt by the upper-middle class to impose on her working class background, and so make her conform to the pretentious values of her new school and new friends. Tomboy Ailsa is proud of her working class origins and likes living on the "wrong side of the tracks" (6) where it is noisy and busy. The environment suits her 
exuberance and physicality, aspects of her personality well illustrated by the fact that she sweats when she plays tennis and grunts when she plays a forehand shot. She is forthright and loud. "Tone yourself down, young lady," (7), the headmistress of Willowbank School has told her:

But you couldn't be toned down after living in a hostel for three years, with women scooting around you like a basketball team. You had to make some noise if you wanted to be heard and you had to go after things and not hang back. She'd seen too many quiet girls weeping in the corner, too many quiet ones all by themselves. (Hostel Girl 7)

Her mother and her teacher Mrs Nimmo urge her to be herself. Mrs Nimmo in particular advises her to "[k]eep on sounding like a New Zealander not all these little misses trying to be Claire Bloom" (59). This is very similar advice to that given by the Gee figure, 'Clippy' Hedges, in The Fire-Raiser - "New Zealanders should talk like New Zealanders and not be little mock-Englishmen" (59) - and reveals Gee's concern with New Zealandness and national identity.

For her part, Mrs Page thinks Ailsa is common and not good enough for Calum. As she tells her husband: "I'd sooner he stayed in a wheelchair than run around with girls of that sort" (109). The implication here is that because Ailsa is working class, her morals are lax. (In a parody of the Mazengarb Report findings, it is the adults in this novel whose morals are suspect, not the adolescents.) Yet the friendship between working class Ailsa and upper middle class Calum may, in fact, anticipate the more egalitarian society that the socialist Gee would like. 


\section{Morality}

Morality can be defined as the right moral conduct in a society. It is a key theme in Hostel Girl and, as we shall see in another set of vignettes, Gee's characters respond differently to its imposition on their lives, whether it arises out of the Mazengarb Report or from within the context of the novel's conservative 1950s.

Mrs McGowan was worried about the reported incidents of sexual immorality at coeducational schools, and Hutt Valley High School in particular:

She wasn't strait-laced at all but being alone had made her uncertain about decisions her husband might have made. School boys and school girls having sex among the gravestones in the cemetery! She must find a school where her daughter would be safe. (Hostel Girl 8).

Whether Ailsa is 'safer' at Willowbank School is debatable. Although it is a church school with its own religious-based morality, the girls are like the girls at Ailsa's old school. They have "all read the stories in Truth and were no different from her - talked a bit different, most of them, and had fathers who were lawyers and ambassadors and MPs; but Ailsa learned new swear words at Willowbank" (8). 'Safe' is a contested word here because the danger for Ailsa, as Trevor Agnew has also pointed out in a review of Hostel Girl (37-38), is not from associating with the wrong kind of youth but from a middle-aged man in her own community.

Gee has made Ailsa a very modern 1950s girl. She wants to know about sex (73), talks about periods (91) and tells Gloria: "There's things you can do [to end a pregnancy]" (92). She even gets the name of a drug that can cause miscarriages, 'stilboestrol', from her geography teacher. Louise Clark takes issue with this depiction of Ailsa, saying that it does 
not reflect 1950s sensibilities ("Writing Vertically and Horizontally" 167). That Ailsa questions the status quo regarding sexuality and morality is anachronistic, says Clark, who goes on to argue her point by comparing Tessa Duder's apparently more conventional character Alex (from the Alex quartet) with Ailsa. ${ }^{44}$ Clark argues that by making Ailsa a feminist Gee is imposing his own view on the reader: "By placing his heroine in opposition to the prevailing mores and attitudes of the time, he is drawing attention to these attitudes and making judgments, rather than letting readers draw their own conclusions" (Clark 167). I have some sympathy for Clark's views, having become irritated at times with Ailsa's precociousness, but admire Gee's ability to write so well from the female perspective.

Prudish Miss Cotter is a long-time resident of the hostel. She has created a role for herself as the sotto voce of the Mazengarb Report, dispensing warnings about 'proper' female behaviour such as "[y]oung girls should keep quiet, especially now" (22) with judgments about 'improper' behaviour, once calling Gloria “[o]ne bad apple” (62). These pronouncements clearly contrast two stereotypical images of women in the Mazengarb Report: passive and permissive. Miss Cotter was someone to avoid:

[...] She had a protruding stomach that she said was a growth and she always wanted to talk about it, even at the table. Ailsa in particular like to keep clear of her. Ever since the sex scandal Miss Cotter had started shooting frowns in her direction. She believed juvenile delinquency was caused by swimming pools, where too much flesh was exposed. 'Flesh' and 'immorality' were her favourite words after 'stomach' and 'growth'. (Hostel Girl 22)

What the Mazengarb Report called 'pre-marital relations' was considered (by the Mazengarb Special Committee at least) "opposed to all the ideas of chastity which are inherent in our morality" (Mazengarb 44). Gloria has had sex with Bevan once and now

\footnotetext{
${ }^{44}$ However, Harry Ricketts suggests “Alex's 'feminism' is evident throughout the quartet in her determinedly independent stance on all issues" ("History" 83).
} 
thinks she is pregnant. She is worried about the stigma of unmarried pregnancy and the knowledge that if she is pregnant, she will have to leave the hostel. For Gloria, a Catholic, there is no abortion and no contraception, but a good deal of guilt. In these circumstances she would feel the double imposition of society's expected moral approbation and Catholicism's teachings on sexual morality.

Errol Parkinson has a different view of morality. If Ailsa is Gee's corrective to the Mazengarb Report's claims of teenage immorality and violence, as claimed earlier in this section, then Errol is surely the report's personification and representative of its moralistic mentality. But his idealisation of women and anger at finding out Gloria is not a virgin, the contradiction between the purity and sexual titillation of the pictures on his wall and his intention to maintain Gloria's 'purity' for his own satisfaction reveal him as immoral and dangerously psychotic. Gee perhaps reconciles these two emblematic positions - Ailsa's corrective to the Mazengarb Report and Errol's personification of the report - only through Errol's horrible death and Ailsa's compassion for him at the end:

Errol Parkinson held out his hands. His mouth opened, showing his bitten tongue. Ailsa could not hear him but imagined ever after that his words were, 'Help me.' He was acting no role; he was someone calling out for her, begging for his life; and she could not reach him. (Hostel Girl 127)

Errol's motivation for his actions is not drawn out by Gee - there is no defining experience in childhood such as Edgar Marwick and Herbert Muskie had - but his piteous end demands some compassion. In showing her compassion for Errol, Ailsa validates those thousands of perfectly normal young New Zealanders who were condemned, by association, as moral delinquents by the Mazengarb Report. 
Ron Stock, boilerman at the YWCA Hostel, represents the positive side of Errol and his obsession. He too is "smitten with Gloria" (55) but, unlike Errol, realises she is out of his league. Regarded as "a bit simple" (19) by Mrs McGowan and made fun of by some of the girls, Ron offers to watch out for the hostel prowler:

"I heard about that feller on the bike."

"What about him?"

"It's her he's after, isn't it?"

"Gloria?"

He nodded. "Her."

"Yes."

"So I'll keep an eye out. I'll watch here."

"We told the police. He won't come back."

"I'll watch a while. Then I'll go." (Hostel Girl 83)

Ron's 'watching' spreads over many nights, and involves hiding in the shrubbery around the hostel (just like the real prowler). His actions are not so different to Errol's prowling except for the motivation. Ron is 'looking out' for Gloria and Errol is 'looking' for her.

Comics were given a bad press in the Mazengarb Report, especially "the more modern style which is basically designed for low-mentality adults" (Mazengarb19). Ron reads comics during smoko (we are not told what kind), drinks from a bone china cup and has fastidious eating habits. It could be that Gee is mocking the Mazengarb Report's description of the modern comics reader by creating one refined comic reader who turns out to be something of a hero by saving Gloria.

In this chapter, social violence is explored as an undercurrent in Gee's two post-war YA novels, Orchard Street and Hostel Girl, following on from its more central role in The Fat Man. Gee depicts two types of social violence in these novels, one in the more traditional sense of acts that impact adversely on society and the other in the less traditional sense of impositions on people's behaviour by society's structures and norms. Looking at Orchard 
Street, we see examples of the first type of social violence that disrupt the pattern of everyday life in the street, namely gossip and crime. Gossip may seem a trivial type of social violence compared with the three crimes committed on the street but as slander and defamation it has a similar potential to injure and upset.

Rather differently, social violence is represented in Hostel Girl as impositions on people's behaviour by society's structures and norms. And Gee is on record for abhorring "imposed uniformity, bureaucratic and institutional repression" (Manhire 10). As my vignettes show, religion, social class and morality place restrictions on the choices women, especially, can make about their lives. Through his portrayal of women in this novel and their responses to the moral and social mores of the novel's 1950s, Gee maps their progress from Mazengarb to assertive feminism. 


\section{Conclusion}

What this thesis first demonstrates is the significant presence of violence in Gee's historical novels for children. That violence is represented in different forms and at different intensities across the five novels in this study. It does not, however, even in The Fat Man, match the physical violence in Gee's fiction for adults. The Fire-Raiser and The Champion depict two forms of systemic violence - war and racism, respectively - and position children as the world's hope for peace and racial equality. The centrepiece of my thesis, The Fat Man, is a psychosociological study of three forms of violence: individual, family and social. This tripartite violence is shown to be an expanding and damaging force across multiple levels of society. And although violence is not the dominant theme in Orchard Street and Hostel Girl, it runs as an undercurrent through these texts as social violence that is as much a response to societal unrest as it is a reaction against existing forces in society. Similar forms of violence overlap the novels. For instance, the racism directed at Lotte Stauffel in The Fire-Raiser becomes the main theme of The Champion and the social violence in The Fat Man spills over into Orchard Street and Hostel Girl. Violence is indeed a persistent force in these novels.

The second point to make is that Gee's treatment of violence is appropriate for his young readers. Talking about his own use of violence in his YA novels, Robert Cormier said: "It is the way that the topics are handled that's important, and that applies whether it is a 15-year-old who is reading your book or someone who is 55" (qtd. in Gardner "Robert Cormier"). Gee handles 'the topics' of his historical novels very well.

Gee makes concessions for his young readers. Adult themes in the first three novels are downplayed, although a careful reader might pick up on Bette's black eyes and wonder 
why (The Fat Man 110). Marwick's cruel incarceration by his mother is not laboured (The Fire-Raiser), Jack is very matter-of-fact when reporting his daddy's death at the hands of the mob (The Champion) and Muskie's intentions for Verna are implied only (The Fat Man). Orchard Street and Hostel Girl are YA novels and so Gee can be more direct in them. Thirteen-year-old Ossie knows about sex and fourteen-year-old Ailsa about pills that can cause a miscarriage.

Furthermore, Gee the humanist always treats his flawed and damaged men with compassion and (seemingly) expects his readers to do the same. Thus Marwick and Muskie's stories of childhood deprivation and ill-treatment are made known; Jack gets sympathy on going AWOL, and Bike gets practical advice from old Redknapp about going to prison. But violence is not privileged. There are always consequences of actions and a price to pay. This makes Gee quite a moral writer, I think - something C.K. Stead has also commented on, in relation to Gee's adult novel, Ellie and the Shadow Man (329).

Distancing helps to keep violence at bay. Stories set in the historical world distance violence from children by time, place and genre. Third person narratives can do this, too, as there is no identification with the worrying 'I' of the first person narrative. (The Fire-Raiser, The Fat Man and Hostel Girl are all third person narratives.) Then there is Gee's intrusive narrator, perhaps an older iteration of the story's protagonist, looking back (so we know it turns out well) and looking forward (anticipating events and reassuring children), as in The Fat Man and Orchard Street.

Importantly, Gee balances violent characters with rational characters as if to provide a viable alternative to violence - thus the Marwick/ Hedges dichotomy, the Rex/Jack dichotomy and the Muskie/Colin dichotomy. What one character is lacking, the other 
compensates for. Colin's responsibility, for example, counterpoints the opposite negative qualities in Muskie while his (Colin's) act of compassion at the end of the novel signals agency and empowerment that young readers might also achieve in their own lives.

It is interesting to consider if there is any redemption for Gee's violent characters. In chapter 3 of my thesis I suggested that Muskie might be redeemed through death. The same might also be said of Errol Parkinson. Marwick, however, gets sent to prison, the last place he should go given his psychological disorder (but there was no counselling or therapy available in 1915). Rex and Bike can be 'saved'. Bike pays the price for his actions in a “pretty grim" prison (Orchard Street 137) and Rex has learnt the lesson of racial tolerance.

My research has shown that violence of all forms is a significant part of Maurice Gee's historical novels for children and that Gee treats it appropriately for his young readers. It would be timely for another researcher to investigate violence across all of Gee's work and to tease out further connections between the adult and children's work, including the fantasies. There is surely more to learn about Gee and his writer's fascination with violence. 


\section{Works Cited}

“About the NZARH.” New Zealand Association of Rationalists and Humanists, n.d. Web. 23 Jan. 2012. <http://www.nzarh.org.nz/about.htm>.

Abrams, M.H. and Geoffrey Galt Harpham. A Glossary of Literary Terms. $9^{\text {th }}$ ed. Boston MA: Wadsworth Cengage Learning, 2009. Print.

Agnew, Trevor. “Extending Readers.” Magpies 14.4 (September 1999): 37-38. Print. Appleyard, J.A. "Later Childhood: The Reader as Hero and Heroine."Becoming a Reader: The Experience of Fiction from Childhood to Adulthood. Cambridge: Cambridge University Press, 1991. 57-93. Print.

"The Authors." Volume 3. Christchurch: Christchurch College of Education Video Production Unit, 1995. Video.

Barber, Laurie. “1901-1930: The Expanding Frontier.” Presbyterians in Aotearoa 1840-1990. Ed. Dennis McEldowney. Wellington: Presbyterian Church of New Zealand, 1990. 74-87. Print.

Barrowman, Rachel. "Writing Lives - Maurice Gee's Biography”. Research Roundup Series. Stout Research Centre, Victoria University of Wellington. 22 Oct. 2008. Seminar presentation.

Bartola, Nicola. "The Sense of Violence in Children's Literature.” Bookbird 31.3 (September 1993): 7. Print.

Bassett, Michael. Confrontation '51: the 1951 Waterfront Dispute. Wellington: Reed, 1972. Print.

Baxter, Archibald. We Will Not Cease. Christchurch: Caxton Press, 1968. Print.

Beatson, Peter. "Maurice Gee.” The Literary Encyclopedia, 13 Mar. 2006. Web. 12 Dec. 2009. < http://www.litencyc.com/php/speople.php?rec=true \&UID=1708> .

Belich, James. Paradise Reforged: A History of the New Zealanders from the 1880s to the Year 2000. Auckland: AllenLane, Penguin, 2001. Print. 
Bertram, James. "Violence in New Zealand Literature." Violence. Ed. J.M. Barrington.

Wellington: Department of Justice, 1971. 1-24. Print.

Boeree, Dr. C. George. “Carl Jung 1875-1961.” Personality Theories. n.d. Web. 12 May

2011. 〈http://webspace.ship.edu/cgboer/jung.html>.

Boock, Paula. “Children's Fiction - What Message?" "Letters". New Zealand Listener

1 Jul. 1995: 13. Print.

Boyd, Brian. "Maurice Gee/Interviewed by Brian Boyd.” In the Same Room:

Conversations with New Zealand Writers. Eds. Elizabeth Alley and Mark Williams.

Auckland: Auckland University Press, 1992. 159-73. Print.

Brett, Cate. "The Gee Genius.” North and South Sep. 1995: 92-101. Print.

Brickell, Chris. "Sexuality, Morality and Society." The New Oxford History of

New Zealand. Ed. Giselle Byrnes. Melbourne: OUP, 2009. 465-486. Print.

Burton, Ormond. A Testament of Peace. Wellington: New Zealand Christian Pacifist Society, 1940. Print.

Butler, Dorothy. "Children's Fiction - What Message?" "Letters". New Zealand Listener 13 May 1995:12. Print.

---."Children's Fiction - What Message?" "Letters”. New Zealand Listener 22 Jul. 1995: 12-13. Print.

The Champion. Dir. Peter Sharp. (TVNZ Archives: ZCHA-89-01 to 06. Eps. 1-6.) TVNZ, 1989. Video.

Chapple, Geoff. “But Earth Shall Glisten.” New Zealand Listener 3 Nov. 1984: 36-38. Print.

---.“Chapple, James Henry George.” Dictionary of New Zealand Biography, 1 Sep. 2010.

Web. 13 Feb. 2011. 〈www.dnzb.govt.nz>.

Clark, Louise. “'Making Its Own History’: New Zealand Historical Fiction for Children, 1862-2008.” Diss. University of Waikato, 2009. Print. 
---. “Writing Vertically and Horizontally: the Relationship Between Maurice Gee’s Fiction for Children and for Adults.” M.Phil. thesis. University of Waikato, 2004. Print.

Condliffe, J.B. A Short History of New Zealand. Christchurch: L.M. Isott, 1925. Print.

Cormier, Robert. The Chocolate War. London: Macmillan, 1978. Print.

Cresswell, Willie. “Children's Fiction - What Message?” "Letters.” New Zealand Listener 22 Jul. 1995: 13. Print.

“Criminal Sittings.” Colonist 21 July 1894: 3. Print.

Czennia, Bärbel. "Cross-cultural Encounters and Xenophobia in Contemporary

New Zealand Children's Literature.” The Inside Story: Year Book 2002: 69-92.

Print.

Dahl, Roald. Charlie and the Chocolate Factory. London: Puffin, 2004. Print.

---. James and the Giant Peach. London: Puffin, 1995. Print.

---. The Witches. New York: Farrar, Straus, Giroux, 1983. Print.

Day, Lorain and Tim Plant. On This Day: New Zealand's Historic Moments. Auckland:

Reed, 2002. Print.

Duder, Tessa. Alessandra. Auckland: OUP, 1991. Print.

---. Alex. Auckland: OUP, 1987. Print.

---. Alex in Winter. Auckland: OUP, 1989. Print.

---. "Much Ado about The Fat Man.” tessaduder.com. Tessa Duder, n.d. Web. 21 Jun. 2010. <http://www.tessaduder.com/res.html $>$.

---. Songs for Alex. Auckland: OUP, 1992. Print.

Duder, Tessa, Wayne Mills, and Hine Elder. “Children's Fiction - What Message?” “Letters.” New Zealand Listener 3 Jun. 1995: 14. Print.

Duffy, Michael. “Timeline.” firstworldwar.com, 22 Aug. 2009. Web. 28 Apr. 2010. <www.firstworldwar.com/index.htm >. 
Eldred-Grigg, Stevan. The Great Wrong War: New Zealand Society in WWI. Auckland:

Random House, 2010. Print.

The Fire-Raiser. Dir. Peter Sharp. (TVNZ Archives: ZFIRE-01-01-05. Eps. 1-5.) TVNZ, 1986. Video.

Fox, Alistair. The Ship of Dreams: Masculinity in Contemporary New Zealand Fiction.

Dunedin: Otago University Press, 2008. Print.

Galtung, Johan. Peace by Peaceful Means: Peace and Conflict, Development and

Civilisation. London: Sage, 1996. 196-210. Print.

Gardner, Lyn. “Robert Cormier.” The Guardian, 6 Nov. 2000. Web. 26 Apr. 2011.

<http://www.guardian.co.uk/news/2000/nov/06/guardianobituaries.books $>$.

Gee, Lyndahl Chapple. “Double Unit.” Speaking for Ourselves. Ed. Frank Sargeson.

Auckland: Caxton, 1945.23-30. Print.

---. Mihi and the Last of the Moas: The Adventures of Mihi, a Little Maori Boy,

With the Very Last of the Moas. Auckland: Oswald-Sealey, 1943. Print.

“Gee, Maurice - author of Blindsight and Salt." penguin.co.nz. Penguin Group (NZ),

26 Sept.2007.Web.8June2010.<http://www.penguin.co.nz/wawcs0131139/idDetails

$=181 /$ Gee, $\% 20$ Maurice\%20-\%20author\%20of\%20Blindsight $\% 20 \& \% 20$ Salt $>$.

Gee, Maurice. "Beginnings.” Islands 5.3 (1997): 284-92. Print.

---. The Burning Boy. London: Viking, 1990. Print.

---. The Champion. Auckland: Puffin, 1989.Print.

---. “Creek and Kitchen.”Through the Looking Glass: Recollections of Childhood from 20

Prominent New Zealanders. Selected and introduced by Michael Gifkins. Auckland:

Century Hutchinson, 1988. 83-92. Print.

---. "Creeks and Kitchens - the Margaret Mahy Lecture.” The Inside Story: Year Book 2002:11-25. Print.

---. Crime Story. Auckland: Penguin, 1994. Print. 
---. "Early Reading: Maurice Gee on Zane Grey.” Education 24.8 (1975): 25. Print.

---. Ellie and the Shadow Man. Auckland: Penguin, 2001. Print.

---. The Fat Man. Auckland: Puffin, 2000. Print.

---. The Fire-Raiser. Auckland: Puffin, 1986. Print.

---. Games of Choice. London: Faber and Faber, 1976. Print.

---. Going West. Auckland: Viking, 1992. Print.

---. The Halfmen of $O$. Auckland: Puffin, 2005. Print.

---. Hostel Girl. Auckland: Puffin, 1999. Print.

---. In My Father's Den. London: Faber, 1972. Print.

---. Loving Ways. Auckland: Penguin, 1996. Print.

---. Meg. London: Faber and Faber, 1981. Print.

---. Motherstone. Auckland: Puffin, 1988. Print.

---. Nelson Central School: a History. Nelson: Nelson Central School Centennial Committee, 1978. Print.

---. Orchard Street. Auckland: Viking, 1998. Print.

---. Plumb. Wellington: OUP, 1979. Print.

---. The Priests of Ferris. Auckland: Puffin, 2005. Print.

---. Prowlers. Auckland: Viking, 1987. Print.

---. Sole Survivor. London: Faber and Faber, 1983. Print.

---. “The Way of a Writer.” New Zealand Listener 17-23 Jan. 1987: 40-42. Print.

Gilderdale, Betty. “Children's Literature.” The Oxford History of New Zealand Literature in English. $2^{\text {nd }}$ ed. Ed. Terry Sturm. Auckland: OUP, 1998. 525-574. Print.

Grace, Patricia. Potiki. Auckland: Penguin, 1986. Print.

Grant, David. The Big Blue: Snapshots of the 1951 Waterfront Lockout. Ed. David Grant.

Christchurch: Canterbury University Press, 2004. 187. Print. 
---. “Burton, Ormond Edward.” Dictionary of New Zealand Biography, 1 Sep. 2010. Web. 25 January 2012. 〈www.dnzb.govt.nz〉.

---. Field Punishment No.1: Archibald Baxter, Mark Briggs and New Zealand's

Anti-militarist Tradition. Wellington: Steele Roberts, 2008. Print.

Heavenly Creatures. Dir. Peter Jackson. WingNut Films, 1994. Film.

Hebley, Diane. The Power of Place: Landscape in New Zealand Children's Fiction, 1970-1989. Dunedin: Otago University Press, 1998. Print.

Heim, Otto. Writing along Broken Lines: Violence and Ethnicity in Contemporary Maori Fiction. Auckland: Auckland University Press, 1998. Print.

“Herbert Sutcliff - Radiant Living." New Zealand History Online, 12 Sep. 2007. Web.

19 Feb. 2012. <http://www.nzhistory.net.nz/culture/radiant-living/herbert-sutcliffe>.

Hewitson, Michele. "Maurice Gee - the Man in a Grey Cardy." New Zealand Herald 29 Jul. 2006: B5. Print.

Heywood, Andrew. Political Ideologies: An Introduction. $4^{\text {th }}$ ed. Basingstoke: Palgrave Macmillan, 2007. Print.

Holloway, Judith. “A Fat Boy, a Creek and Personal Responsibility.” New Zealand Books 5.3 (August 1995): 22-23. Print.

Hourihan, Margery. "Versions of the Past: The Historical Novel in Children's Literature." Give Them Wings: The Experience of Children's Literature. $2^{\text {nd }}$ ed. Eds. Maurice Saxby and Gordon Winch. Melbourne: MacMillan, 1991. 163-176. Print.

Hulme, Keri. the bone people. Auckland: Spiral /Hodder and Stoughton, 1985. Print.

“Humbug." The Concise Oxford Dictionary. $8^{\text {th }}$ ed. 1990. Print.

Hyde, Robin. Nor the Years Condemn. Dunedin: University of Otago Press, 1995. Print. Ihimaera, Witi. The Matriarch. Auckland: Heinemann, 1986. Print.

Ireland, Kevin. "One of the Bohemians." One of the Boys? Changing Views of Masculinity in New Zealand. Ed. Michael King. Auckland: Heinemann, 1988. 88-107. Print. 
Jackson, Anna. "Englishness.” A Made-Up Place: New Zealand in Young Adult Fiction. Ed. Anna Jackson et al. Wellington: Victoria University Press, 2011. 43-67. Print.

Jarvis, Christina. "Violence." The Oxford Companion to the Body. Eds. Colin Blakemore and Sheila Jennett. encyclopedia.com, n.d. Web. 15 June 2010. http://www.encyclopedia.com/doc/10128-violence.html.

Jenkin, Douglas. "Out of the Footlights, Into the Fire.” New Zealand Listener 23-29 Aug.1986: 19. Print.

Jensen, Kai. Whole Men: The Masculine Tradition in New Zealand Literature. Auckland: Auckland University Press, 1996. Print.

Johnson, Tracy. "Children's Fiction - What Message?" "Letters.” New Zealand Listener 22 Jul. 1995: 13. Print.

Jones, Lawrence. "Puritanism." The Oxford Companion to New Zealand Literature. Eds. Roger Robinson and Nelson Wattie. Melbourne: Oxford University Press, 1998. 455-456. Print.

King, Michael. The Penguin History of New Zealand. Auckland: Penguin, 2003. Print. Lasenby, Jack. "Children's Fiction - What Message?" "Letters.” New Zealand Listener 1 Jul. 1995: 13. Print.

---. The Mangrove Summer. Auckland: Oxford University Press, 1988. Print.

McLauchlan, Gordon. The Passionless People. Auckland: Cassell New Zealand, 1976. Print.

McLeod, Marion. “A Champion Tale.” New Zealand Listener 7 Oct. 1989: 29. Print. Mahy, Margaret. Underrunners. London: Hamish Hamilton, 1992. Print.

Manhire, Bill. Maurice Gee. Auckland: OUP, 1986. Print.

Mazengarb, Oswald Chettwin (chairman). Report of the Special Committee on Moral Delinquency in Children and Adolescents. Wellington: R.E. Owen Government Printer, 1954. Print. 
Mein Smith, Philippa. A Concise History of New Zealand. Cambridge and Melbourne:

Cambridge University Press, 2005. Print.

Mercer, Erin. “Monstrous Identities: Critical Realism and Gothic Fantasy in Maurice Gee's The Fire-Raiser." The Journal of Commonwealth Literature 45.1 (2010): 23-35.

Print.

Militch, Michelle. “Children's Fiction - What Message?” "Letters.” New Zealand Listener 22 Jul. 1995: 13. Print.

Moffat, Kirstine. "The Puritan Paradox: The Puritan Legacy in the Intellectual, Cultural, and Social Life of New Zealand, Focusing Primarily on the Works of Novelists Writing Between 1862 and 1940.” Diss. Victoria University of Wellington, 1999. Print.

Morrieson, Ronald Hugh. The Scarecrow. Auckland: Reed, 2002. Print.

Mulgan, John. Man Alone. $3^{\text {rd }}$ ed. Auckland: Longman Paul, 1969. Print.

Nieuwenhuizen, Agnes. “Creek, Kitchen and the Art of Language.” Magpies 12.1 (1997): 4-6. Print.

Nimon, Maureen. "Violence in Children's Literature Today." Dreams and Dynamics.

Selected Papers from the Annual Conference of the International Association of School Librarianship. Adelaide, Australia. September 27-30 1993. Address.

“NZARH Honorary Associates.” New Zealand Association of Rationalists and Humanists, n.d. Web. 21 Jun. 2010. <http://www.nzarh.org.nz/honassoc.htm>.

O’Brien, Gregory. "Making Sentences Work." Moments of Invention: Portraits of 21 New Zealand Writers. Ed. Gregory O’Brien, Auckland: Heinemann Reed, 1988. 112-118. Print.

---. A Nest of Singing Birds: 100 Years of the New Zealand School Journal. Wellington: Learning Media, 2007. Print.

Oliver, W.H., with B.R. Williams, eds. The Oxford History of New Zealand. 
Wellington: OUP, 1981. Print.

“Our Empire Day”. Maurice Gee Collection, MS-papers-4698-105. Alexander Turnbull Library, Wellington. Print.

"Pamphlet of Humanism in New Zealand." Humanist Society of New Zealand. 10 Jul. 2006.

Web. 25 May 2010. <http://www.humanist.org.nz/pamphlethumanism.html>.

Pearson, Bill. Coal Flat. Auckland: Oxford University Press, 1985. Print.

---. "Fretful Sleepers." Fretful Sleepers and Other Essays. Auckland:

Heinemann, 1974: 1-32. Print.

Phillips, Jock. A Man's Country? The Image of the Pakeha Male: A History. $2^{\text {nd }}$ ed. Auckland: Penguin, 1996. Print.

Purcell, Uta. "The Fat Man by Maurice Gee: Who is the Implied Reader?" Talespinner 2 Nov. (1996): 44-50. Print.

Rhodes, Winston, H. New Zealand Novels: A Thematic Approach. Wellington: New Zealand University Press, Price Milburn, 1968. Print.

Rice, Geoffrey, W., ed. The Oxford History of New Zealand. $2^{\text {nd }}$ ed. Auckland: OUP, 1992. Print.

Ricketts, Harry. "History.” A Made-Up Place: New Zealand in Young Adult Fiction. Eds. Anna Jackson et al. Wellington: Victoria University Press, 2011. 68-86. Print. Ritchie, Jane, and James Ritchie. "The Rainbow Path to Overcoming Violence.”

Overcoming Violence in Aotearoa New Zealand: A Contribution to the World Council of Churches Decade to Overcome Violence 2001-2010. Jane and James Ritchie et al. Wellington: Philip Garside, 2002. 8-17. Print.

---. Violence in New Zealand. $2^{\text {nd }}$ ed. Wellington: Daphne Brasell Associates Press and Huia, 1993. Print.

The School Journal. Part 3 Classes 5 and 6. Vol. IX No.1- No.10. Wellington: New Zealand Dept. of Education, 1915. Print. 
Scott, Dick. 151 Days: History of the Great Waterfront Lockout and Supporting Strikes, February 15 - July 15 1951. Auckland: Southern Cross Books, 1954. Print.

“Secular Humanist Morality.” New Zealand Association of Rationalists and Humanists, n.d.

Web. 8 Sep. 2011. 〈http://www.nzarh.org.nz/morality.htm>.

Shuker, Roy, and Roger Openshaw, with Janet Soler. Youth, Media \& Moral Panic in New Zealand: From Hooligans to Video Nasties. Palmerston North: Dept.

Education, Massey University, 1990. Print.

Simpson, Tony. The Sugarbag Years: An Oral History of the 1930s Depression in New Zealand. Martinborough, New Zealand: Alister Taylor, 1974. Print.

Sinclair, Keith. A Destiny Apart: New Zealand's Search for National Identity. Wellington: Allen \& Unwin, 1986. Print.

---. A History of New Zealand. Rev. and enl. ed. London: A. Lane, 1980. Print.

Smithies, Grant. “Maurice Gee, Master Storyteller.” Stuff. 10 Apr. 2009. Web. 21 Jun. 2010. <http://www.stuff.co.nz/sunday-star-times/features/2926645/Maurice-Gee-master$\underline{\text { storyteller>. }}$

Spoonley, Paul. Racism and Ethnicity. $2^{\text {nd }}$ ed. Auckland: OUP, 1993. Print.

“Squarehead, n.” oed.com. Oxford English Dictionary, Dec. 2011. Web. 3 Feb. 2012. <http://www.oed.vuw.ac.nz/view/Entry/188200>.

Stead, C.K. "Maurice Gee, Moralist.” Kin of Place: Essays on 20 New Zealand Writers. Auckland: Auckland University Press, 2002. 320-29. Print.

Stone, Brenda. "Human Cruelty Explored.” English in Aotearoa. 30 (Dec.1996): 90-93. Print.

Taylor, Nancy M. The New Zealand People at War: The Home Front (Volume 1). Wellington: Historical Publications Branch, Dept. of Internal Affairs; Government Printer, 1986. 171-208. Print. 
Tomlinson, Carl. “Justifying Violence in Children's Literature.” Battling Dragons: Issues and Controversies in Children's Literature. Ed. Susan Lehr. Portsmouth, NH: Heinemann, 1995. 39-50. Print.

van Rij, Vivien. “The Pursuit of Wholeness in Maurice Gee's Fiction for Children.” Diss. Victoria University of Wellington, 2008. Print.

von Franz, Marie-Louise. “The Process of Individuation.” Man and His Symbols. Ed. Carl G. Jung. New York: Dell, 1968. 157-254. Print.

Walls, Kathryn. "Māori and Pākehā." A Made-Up Place: New Zealand in Young Adult Fiction. Eds. Anna Jackson et al. Wellington: Victoria University Press, 2011. 2742. Print.

Wattie, Nelson. "Gee, Maurice.” The Oxford Companion to New Zealand Literature. Eds. Roger Robinson and Nelson Wattie. Melbourne: Oxford University Press, 1998. 197-199. Print.

Welch, Denis. “Gee Gee: Maurice Gee’s Brilliant Plagiarisms of Maurice Gee.” New Zealand Listener 12 May 2001: 58-59. Print.

West, Mark. "Regression and Fragmentation of the Self in James and the Giant Peach." Children's Literature in Education 16.4 (Winter 1985): 219-25. Print.

---. "Roald Dahl.” Trust Your Children: Voices against Censorship in Children's Literature. New York: Neal-Schuman, 1988. 71-76. Print.

Williams, Mark. "Maurice Gee: Mistakes and Miracles.” Leaving the Highway: Six Contemporary New Zealand Novelists. Auckland: Auckland University Press, 1990. 69-89. Print.

Yska, Redmer. All Shook Up: The Flash Bodgie and the Rise of the New Zealand Teenager in the Fifties. Auckland: Penguin, 1993. Print. 
---. 'Spies, Lies and Red Herrings." The Big Blue: Snapshots of the 1951 Waterfront

Lockout. Ed. David Grant. Christchurch: Canterbury University Press, 2004. 22-29.

Print. 